University of Nebraska - Lincoln

DigitalCommons@University of Nebraska - Lincoln

$1-17-2011$

\title{
Secondary minerals from extrapedogenic per latus acidic weathering environments at geomorphic edges, Eastern Nebraska, USA
}

Robert Matthew Joeckel

K.D. Wally

B.J. Ang Clement

P.R. Hanson

J.S. Dillon

See next page for additional authors

Follow this and additional works at: https://digitalcommons.unl.edu/conservationsurvey

Part of the Geology Commons, Geomorphology Commons, Hydrology Commons, Paleontology Commons, Sedimentology Commons, Soil Science Commons, and the Stratigraphy Commons

This Article is brought to you for free and open access by the Natural Resources, School of at DigitalCommons@University of Nebraska - Lincoln. It has been accepted for inclusion in Conservation and Survey Division by an authorized administrator of DigitalCommons@University of Nebraska - Lincoln. 
Authors

Robert Matthew Joeckel, K.D. Wally, B.J. Ang Clement, P.R. Hanson, J.S. Dillon, and S.K. Wilson 


\title{
Secondary minerals from extrapedogenic per latus acidic weathering environments at geomorphic edges, Eastern Nebraska, USA
}

\author{
R.M. Joeckel ${ }^{\mathrm{a}, \mathrm{b}, *}$, K.D. Wally $^{\mathrm{c}}$, B.J. Ang Clement ${ }^{\mathrm{d}}$, P.R. Hanson ${ }^{\mathrm{a}}$, J.S. Dillon ${ }^{\mathrm{e}}$, S.K. Wilson ${ }^{\mathrm{f}}$ \\ ${ }^{a}$ Faculty of Geology and Soils, Faculty of Geography, Conservation and Survey Division, School of Natural Resources, 615 Hardin Hall, University of Nebraska-Lincoln, Lincoln, \\ NE 68583-0996, USA \\ ${ }^{\mathrm{b}}$ Department of Earth and Atmospheric Sciences, Bessey Hall, University of Nebraska-Lincoln, NE 68588-0340, USA \\ ' Waste Management Division, Department of Environmental Quality, State of Nebraska, Suite 400, The Atrium, 1200 'N' Street, P.O. Box 98922, Lincoln, NE 68509-8922, USA \\ ' Department of Biology, Doane College, 1014 Boswell Avenue, Crete, NE 68333, USA \\ e Department of Geography and Earth Science, University of Nebraska-Kearney, 203 Copeland Hall, Kearney, NE 68849, USA \\ ${ }^{\mathrm{f}}$ Northern Great Plains Inventory and Monitoring, National Park Service, 231 East St. Joseph, Rapid City, SD 57701, USA
}

\section{A R T I C L E I N F O}

\section{Article history:}

Received 4 August 2009

Received in revised form 17 December 2010 Accepted 17 January 2011

\section{Keywords:}

Alunite

Aluminite

"Basaluminite"/felsöbányaite

Gibbsite

Vashegyite

Pyrite oxidation

\begin{abstract}
A B S T R A C T
Acidic weathering of the sulfidic Upper Cretaceous Carlile and Pierre Shales in Nebraska has led to the precipitation of the $\mathrm{Al}$ sulfate-hydroxide minerals aluminite, alunite, "basaluminite"/felsöbányaite (e.g.,), the aluminum hydroxides gibbsite and bayerite, and the rare $\mathrm{Al}$ phosphate hydroxide vashegyite. Kaolinite has also been produced as a result of this acidic weathering. These minerals do not appear as neoformed constituents in any extant soils in the region, and their existence underscores the ability of pyrite oxidation to produce major changes in mineralogy on a Holocene to Recent time scale. Jarosite, hydronium jarosite, gypsum, halotrichite, and melanterite also appear as secondary minerals in the weathered shales. Acidic weathering and the formation of new minerals is extrapedogenic because it occurs well below the limit of modern soil sola. These processes also occur at the edges of major landscape elements and can be considered to have a strong lateral component processes, making them "per latus" processes in our usage.
\end{abstract}

(c) 2011 Elsevier B.V. All rights reserved.

\section{Introduction}

Accounts of natural acidic weathering resulting from pyrite oxidation in sedimentary rocks are much fewer than those of acid mine drainage (e.g., Nordstrom and Alpers, 1999; Blowes et al., 2004), and in many places it has been overlooked as a potentially common near-surface process. Acid-weathering Cretaceous shales, such as those discussed in this study, are very widely distributed and crop out extensively in the Western Interior of North America (e.g., Gautier, 1986; Arthur and Sageman, 1994). The weathering of these shales has received very little attention (e.g., Eberlin, 1985), and the occurrence of many of the resultant secondary minerals was essentially unknown until now. We present evidence for the occurrence of natural acidic weathering in two widespread, sulfide-bearing Cretaceous shales in Nebraska, the Carlile Shale (Fig. 1a: sites 1 and 2) and the Pierre Shale (Fig. 1a: site 3) has produced multiple new mineral phases that are nothing less than exotic in the contexts of regional soil-related weathering and the current state of scientific literature. These sites are

\footnotetext{
* Corresponding author at: Faculty of Geology and Soils, Faculty of Geography, Conservation and Survey Division, School of Natural Resources, 615 Hardin Hall, University of Nebraska-Lincoln, Lincoln, NE 68583-0996, USA. Tel.: + 1402472 7520; fax: +1 402472460 .

E-mail address: rjoeckel3@unl.edu (R.M. Joeckel).
}

broadly characteristic of weathering processes that must exist wherever these and other Cretaceous shales are exposed in the enclosing region, making our results widely applicable in the understanding of underappreciated aspects of environmental mineralogy and chemistry.

We employ the term "extrapedogenic" in this study to emphasize that the weathering we describe occurs below the level of the soil solum. The effects of weathering at the sites we describe are also concentrated at the edges of major geomorphic elements (valley walls and major rivers) by groundwater discharge, evaporation, and oxidation associated with proximity to the atmosphere. Therefore, we also describe the weathering we observe as a per latus process, that is, having a strong lateral component, in contrast to per ascensum (operating vertically upward) or per descensum (operating vertically downward) processes. Per latus weathering in the cases we describe occurs at geomorphic edges exposing reactive bedrock and involves the: (1) widespread, diffuse discharge of groundwater and, probably, intermittent and more concentrated discharge; (2) evaporation and oxidation near the interface between the lithosphere and the atmosphere accumulation of secondary minerals along near-surface fractures and joints; (3) formation of authigenic nodules near the same surfaces; and (4) development of efflorescences at outcrop faces on geomorphic edges. In total, per latus weathering contrasts with the downward migration of a regional weathering front and progressive 
a
SOUTH D A KOTA

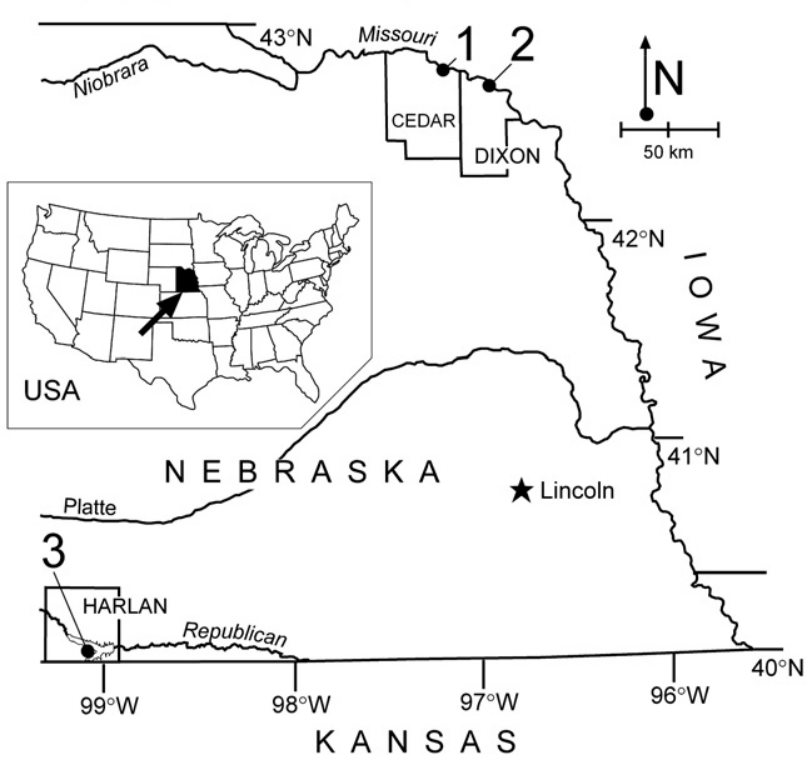

b

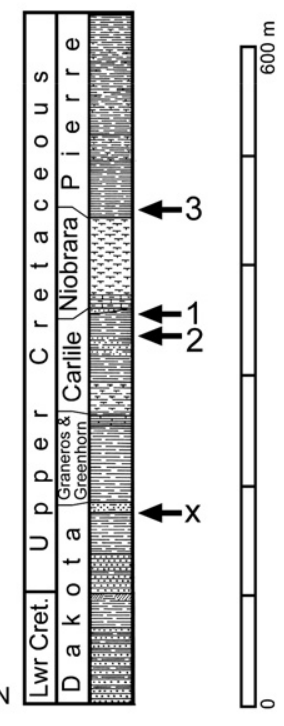

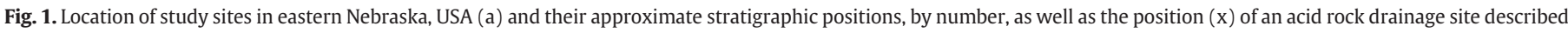
by Joeckel et al. (2005) (b). Composite stratigraphic section of formations of Cretaceous System in Nebraska modified after Condra and Reed (1959) omits upper Pierre Shale.

in-situ alteration of bedrock by per descensum processes. Acknowledgement of acidic rock weathering in the context of extrapedogenic and per latus processes expands the overall paradigm for rock weathering and mineral neoformation and transformation in a midlatitude, subhumid, continental climatic setting.

\section{Materials and methods}

Nodules and crusts of secondary minerals, alteration zones, and weathered rock at three sites on naturally acid-weathering, pyritebearing Cretaceous sedimentary rocks in Nebraska (Fig. 1) were collected and stored in sealed plastic bags at room temperature. The study sites and the materials collected from them are described in detail in a forthcoming section.

Subsamples of materials collected at the study sites were processed and analyzed by X-ray diffraction (XRD), within a month after collection and within two hours after their removal from storage bags. Prior to XRD analysis, subsamples were powdered using a ceramic mortar; manual grinding was limited to less than one minute to minimize its peak-broadening effect on X-ray diffractograms. To obtain randomly oriented powder mounts, ground subsamples were screened to minus $63 \mu \mathrm{m}$, and the oversize fraction was rejected. A Rigaku Mini-Flex ${ }^{\mathrm{TM}}$ X-ray diffractometer using $\mathrm{CuK \alpha}$ radiation at $30 \mathrm{kV}$ and $15 \mathrm{~mA}$ was employed for XRD analysis. Scans were made from $2^{\circ}$ to $90^{\circ} 2 \Theta$ at a step time of $1^{\circ}$ or $2^{\circ} 2 \Theta / \mathrm{min}$. Mineral identification was facilitated by the search-match function in JADE ${ }^{\mathrm{TM}}$ release 8 software from Materials Data, Inc. (Livermore, CA), which uses the Powder Diffraction Files or PDFs (International Centre for Diffraction Data, 2001) as references. Repeated onscreen qualitative comparisons of diffractograms and match lines were employed in addition to peak-matching software. A Hitachi S-3000N scanning electron microscope (SEM) was used to examine and image Pt-Pd coated samples of secondary minerals and weathered host materials. Many of these samples required multiple iterations of coating in order to stabilize them and prevent excess charging under the electron beam. The colors of mineral crusts and weathered materials are expressed according to the Munsell Soil Color Charts (Munsell Color, 1998).

\section{Results}

All three study sites exhibit intense chemical weathering phenomena relative to regional soils, and weathered shales at each site produce $\mathrm{pH}$ values of 3-5 in 1:1 suspensions in deionized water. Also, all three sites are located in extensive bedrock exposures along the sides of major river valleys that include stratigraphic contacts that serve as near-surface discontinuities affecting the movement of groundwater. These discontinuities are also the prime loci for weathering effects. Weathering and the formation of new minerals at all three sites must be in large measure a geologically recent phenomenon, since it is dependent on the existence of outcrops that undergo varying degrees of active mass wasting.

Table 1

Minerals discussed in this study.

\begin{tabular}{|c|c|}
\hline Mineral & Formula \\
\hline Alunogen $^{\mathrm{a}}$ & $\mathrm{Al}_{2}\left(\mathrm{SO}_{4}\right)_{3} \cdot 17 \mathrm{H}_{2} \mathrm{O}$ \\
\hline Alunite $^{\mathrm{b}, \mathrm{c}}$ & $\mathrm{KAl}_{3}\left(\mathrm{SO}_{4}\right)_{2}(\mathrm{OH})_{6}$ \\
\hline Aluminite $e^{\mathrm{b}, \mathrm{c}}$ & $\mathrm{Al}_{2}\left(\mathrm{SO}_{4}\right)(\mathrm{OH})_{4} \cdot 7 \mathrm{H}_{2} \mathrm{O}$ \\
\hline Bayerite $e^{b, c}$ & $\mathrm{Al}(\mathrm{OH})_{3}$ \\
\hline Copiapite $^{a}$ & $\mathrm{Fe}^{2+} \mathrm{Fe}^{3+}{ }_{4}\left(\mathrm{SO}_{4}\right)_{6}(\mathrm{OH})_{2} \cdot 20 \mathrm{H}_{2} \mathrm{C}$ \\
\hline Fluorapatite $e^{b, c}$ & $\mathrm{Ca}_{5}\left(\mathrm{PO}_{4}\right)_{3} \mathrm{~F}$ \\
\hline Felsöbányaite/“basaluminite”a,b,d & $\mathrm{Al}_{4}\left(\mathrm{SO}_{4}\right)(\mathrm{OH})_{10} \cdot 5 \mathrm{H}_{2} \mathrm{O}$ \\
\hline Gibbsite $^{\mathrm{b}, \mathrm{c}}$ & $\mathrm{Al}(\mathrm{OH})_{3}$ \\
\hline Gypsum $^{\mathrm{a}, \mathrm{b}}$ & $\mathrm{CaSO}_{4} \cdot 2 \mathrm{H}_{2} \mathrm{O}$ \\
\hline Halotrichite $^{\mathrm{a}, \mathrm{b}}$ & $\mathrm{Fe}^{2+} \mathrm{Al}_{2}\left(\mathrm{SO}_{4}\right)_{4} \cdot 22 \mathrm{H}_{2} \mathrm{O}$ \\
\hline Hohmannite ${ }^{a}$ & $\mathrm{Fe}^{3+}{ }_{2}\left(\mathrm{SO}_{4}\right)_{2}(\mathrm{OH})_{2} \cdot 7 \mathrm{H}_{2} \mathrm{O}$ \\
\hline Hydronium jarosite ${ }^{b, c}$ & $\left(\mathrm{H}_{3} \mathrm{O}\right) \mathrm{Fe}_{3}\left(\mathrm{SO}_{4}\right)_{2}(\mathrm{OH})_{6}$ \\
\hline Hydroxylapatite ${ }^{b, c}$ & $\mathrm{Ca}_{5}\left(\mathrm{PO}_{4}\right)_{3} \mathrm{OH}$ \\
\hline Jarosite $\mathrm{a}^{\mathrm{a}, \mathrm{b}}$ & $\mathrm{KFe}^{3+}{ }_{3}\left(\mathrm{SO}_{4}\right)_{2}(\mathrm{OH})_{6}$ \\
\hline Melanterite $^{\mathrm{a}, \mathrm{b}}$ & $\mathrm{Fe}^{2+} \mathrm{SO}_{4} \cdot 7 \mathrm{H}_{2} \mathrm{O}$ \\
\hline Meta-alunogen ${ }^{\mathrm{a}}$ & $\mathrm{Al}_{4}\left(\mathrm{SO}_{4}\right)_{6} \cdot 26 \mathrm{H}_{2} \mathrm{O}$ \\
\hline Metahohmannite ${ }^{a}$ & $\mathrm{Fe}^{3+}{ }_{2} \mathrm{O}\left(\mathrm{SO}_{4}\right)_{2} \cdot 4 \mathrm{H}_{2} \mathrm{O}$ \\
\hline Vashegyite $^{\mathrm{b}, \mathrm{c}}$ & $\mathrm{Al}_{6}\left(\mathrm{PO}_{4}\right)_{5}(\mathrm{OH})_{3} \cdot 23 \mathrm{H}_{2} \mathrm{O}$ \\
\hline
\end{tabular}

a Previously described from Nebraska.

b Identified from at least one site described in this study.

c Not previously described from Nebraska.

d Various databases (e.g., International Centre for Diffraction Data, 2001) still list felsöbányaite and basaluminite as different minerals, but the latter is probably only a microcrystalline variety of the former (Farkas and Pertlik, 1997), and the name "felsöbányaite" has priority (Jambor et al., 1998). 
We emphasize the discovery of particular secondary minerals: (1) the Al sulfate-hydroxide minerals aluminite, alunite, and "basaluminite"/felsöbányaite (Table 1, Fig. 2); (2) the aluminum hydroxide gibbsite, and probable bayerite as well, which co-occur with secondary Al sulfate hydroxides; (3) the rare aluminum phosphatehydroxide vashegyite (Table 1, Fig. 3), which appears as secondary coatings on phosphate nodules at two sites, and which has not heretofore been described from an environment of acidic weathering in sedimentary rocks; and (4) secondary kaolinite. The latter occurrence is significant because the major Cretaceous marine shales in the Western Interior of the USA are overwhelmingly smectitic, containing abundant smectite and illite/smectite (e.g., Tourtelot et al., 1960; Schultz, 1978), and we are unaware of any primary sedimentary accumulation of kaolinite in any of them.

\subsection{Site 1: East of the mouth of Bow Creek, Cedar County, Nebraska}

Site $1\left(\sim 42^{\circ} 45^{\prime} 56^{\prime \prime} \mathrm{N} 97^{\circ} 7^{\prime} 59^{\prime \prime} \mathrm{W}\right)$ is a high, north-facing natural bluff along the Missouri River, east of the mouth of Bow Creek in Cedar County, Nebraska (Figs. 1, 4, 5). It exposes the upper Carlile Shale and part of the overlying Niobrara Formation, which are, in turn, overlain by Late Pleistocene Peoria Loess and Holocene colluvium. Complex slump-earthflows are common in the high bluffs along the banks of the river. Fresh headscarps, headscarp pools, rotated blocks, hummocky toeslopes with mudflows, and other features indicate that mass-movement is an ongoing process. Groundwater seepage has taken place at the contact between the Niobrara Formation and the underlying Carlile Shale recently because seepage can be identified in active mass wasting features in the same area. Likewise, meteoric waters doubtless infiltrated fractures and former mass-wasting slip planes, which now show evidence of weathering, just as they can be seen to migrate through analogous features at the site today. Acidic weathering probably had some effect on mass wasting at site 1 because of the changes it has produced in mineralogy and rock fabric near the outcrop face.

A yellowish brown (10YR 5/6) and brownish yellow (10YR 6/6), soft, earthy alteration zone in the uppermost Carlile Shale at the site is rich in kaolinite (Figs. 4, 5). Approximately 20\% (by volume) of this zone is 5 to $40 \mathrm{~mm}$, very soft, white $(\sim 5 \mathrm{Y} 8 / 1)$, irregular nodules of secondary Al minerals (Fig. 3b). Gypsum crystals constitute another $\sim 10 \%$ of the alteration zone. This alteration zone continues to the west and downslope, where the same very soft, white nodules are also common in a 4 to $20 \mathrm{~cm}$-thick zone that lies between comparatively permeable colluvium containing chalky limestone blocks from the Niobrara Formation and weathered fragments of Carlile Shale, and the less-permeable, in-situ weathered
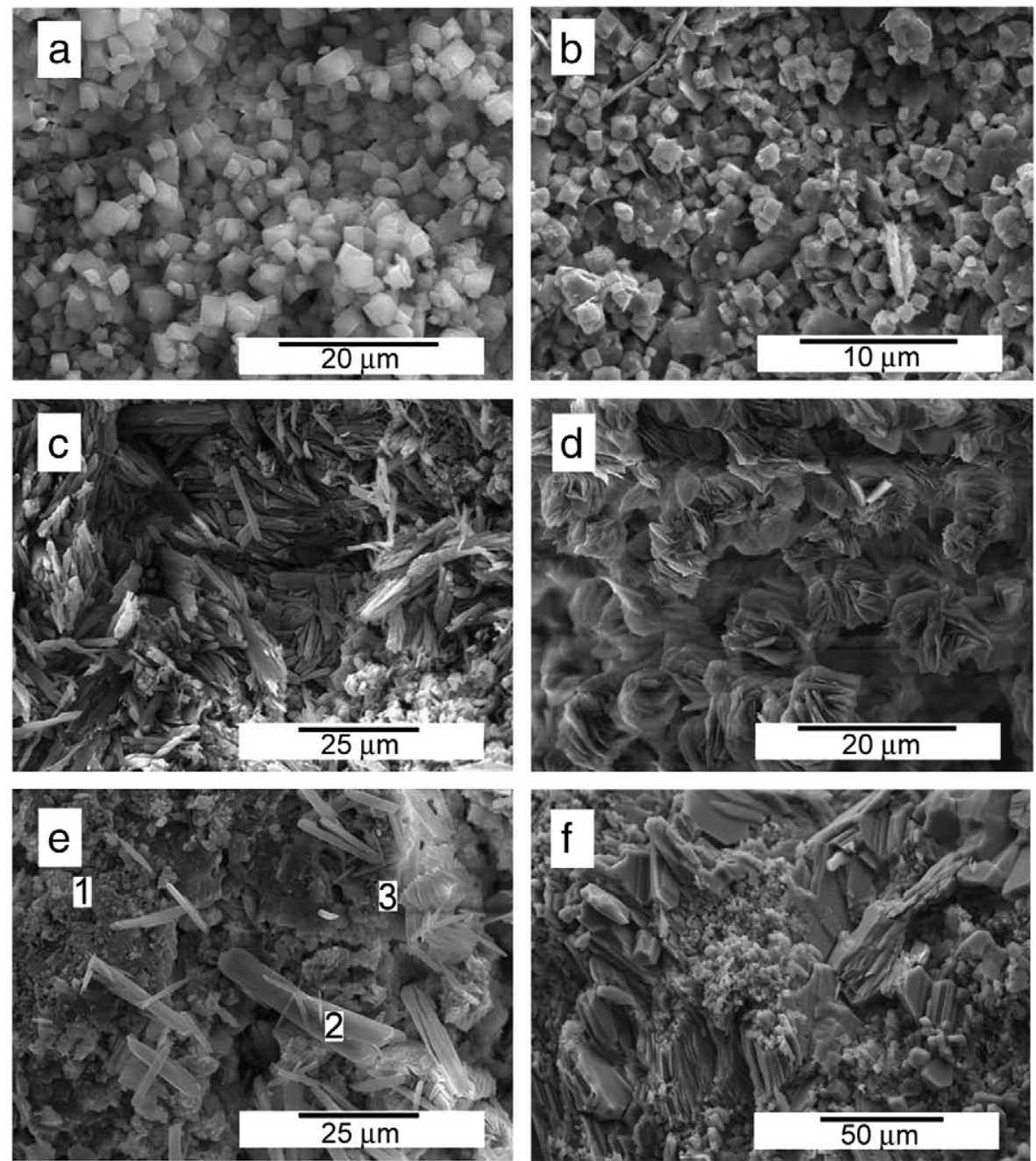

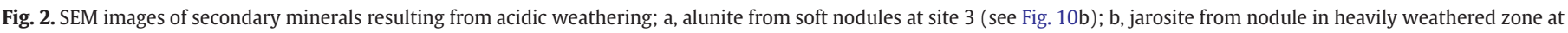

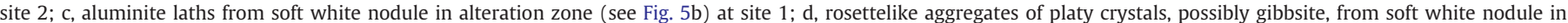

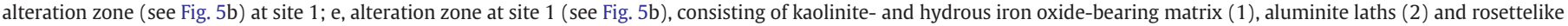

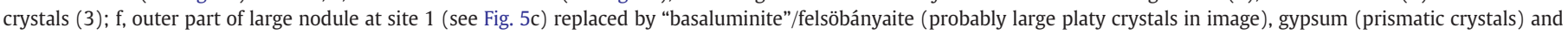
aluminite. 

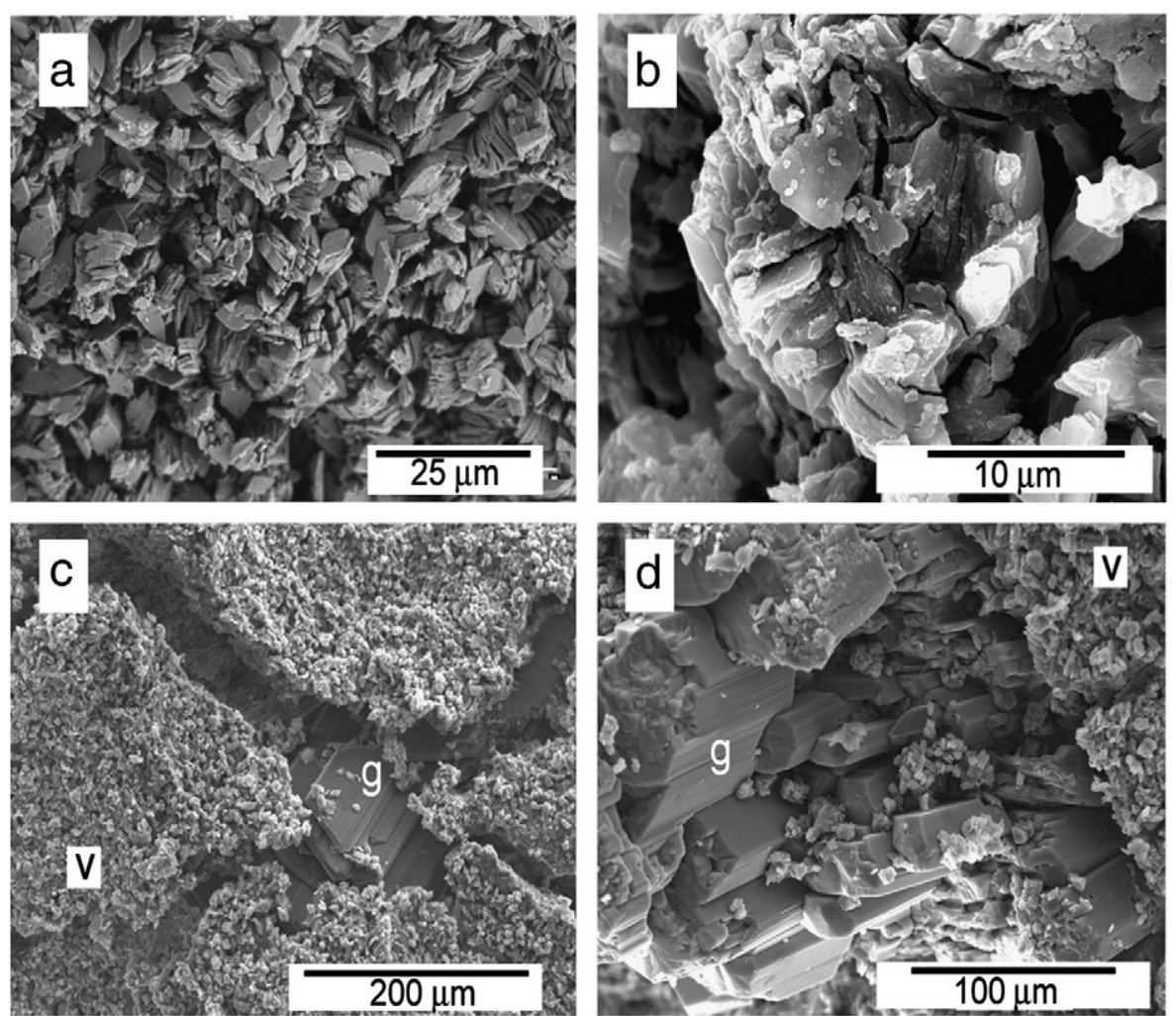

e

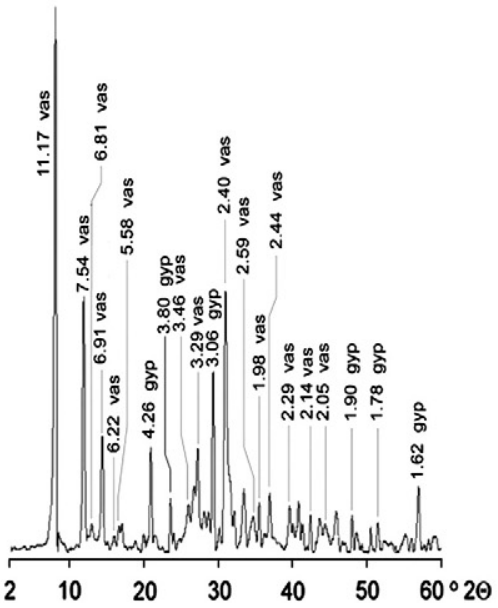

f

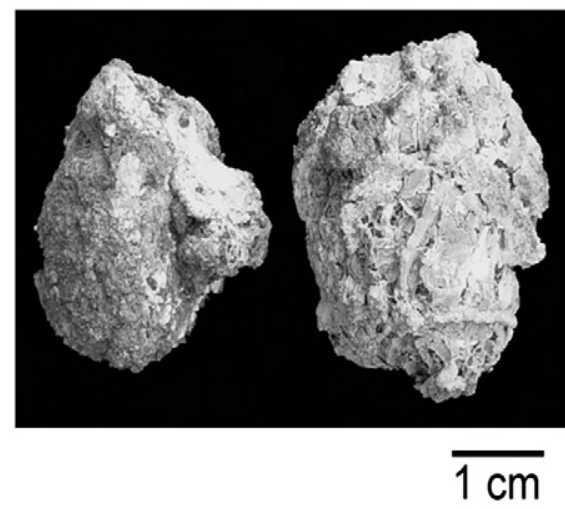

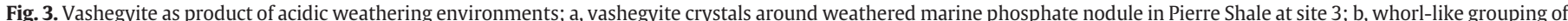

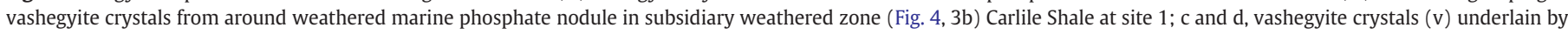

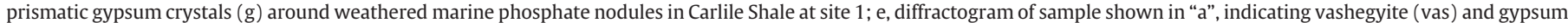
(gyp); f, marine phosphate nodules from site 1 encased in white weathering rinds consisting of vashegyite and gypsum.

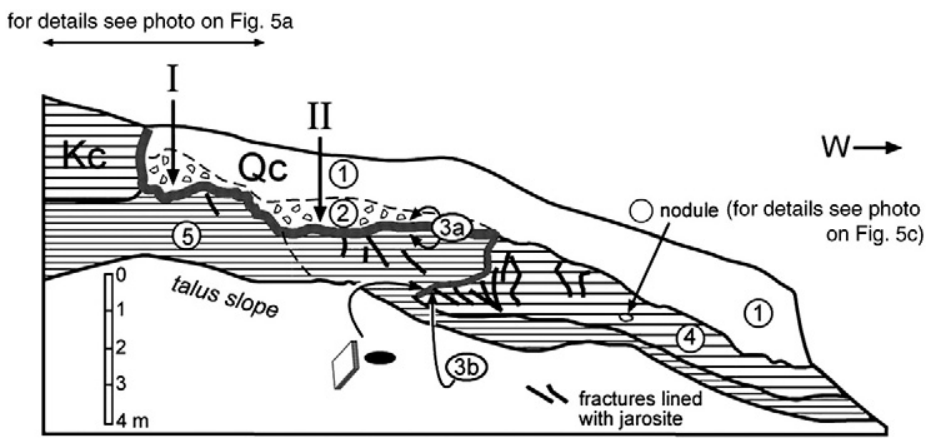

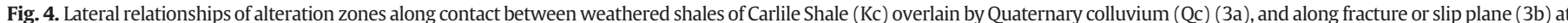

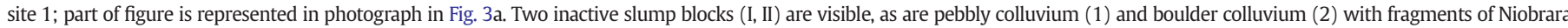

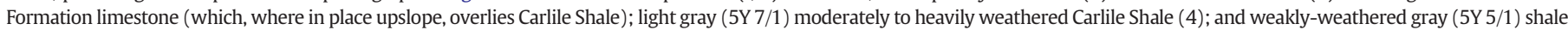

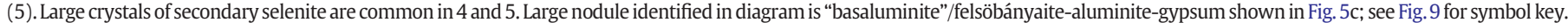



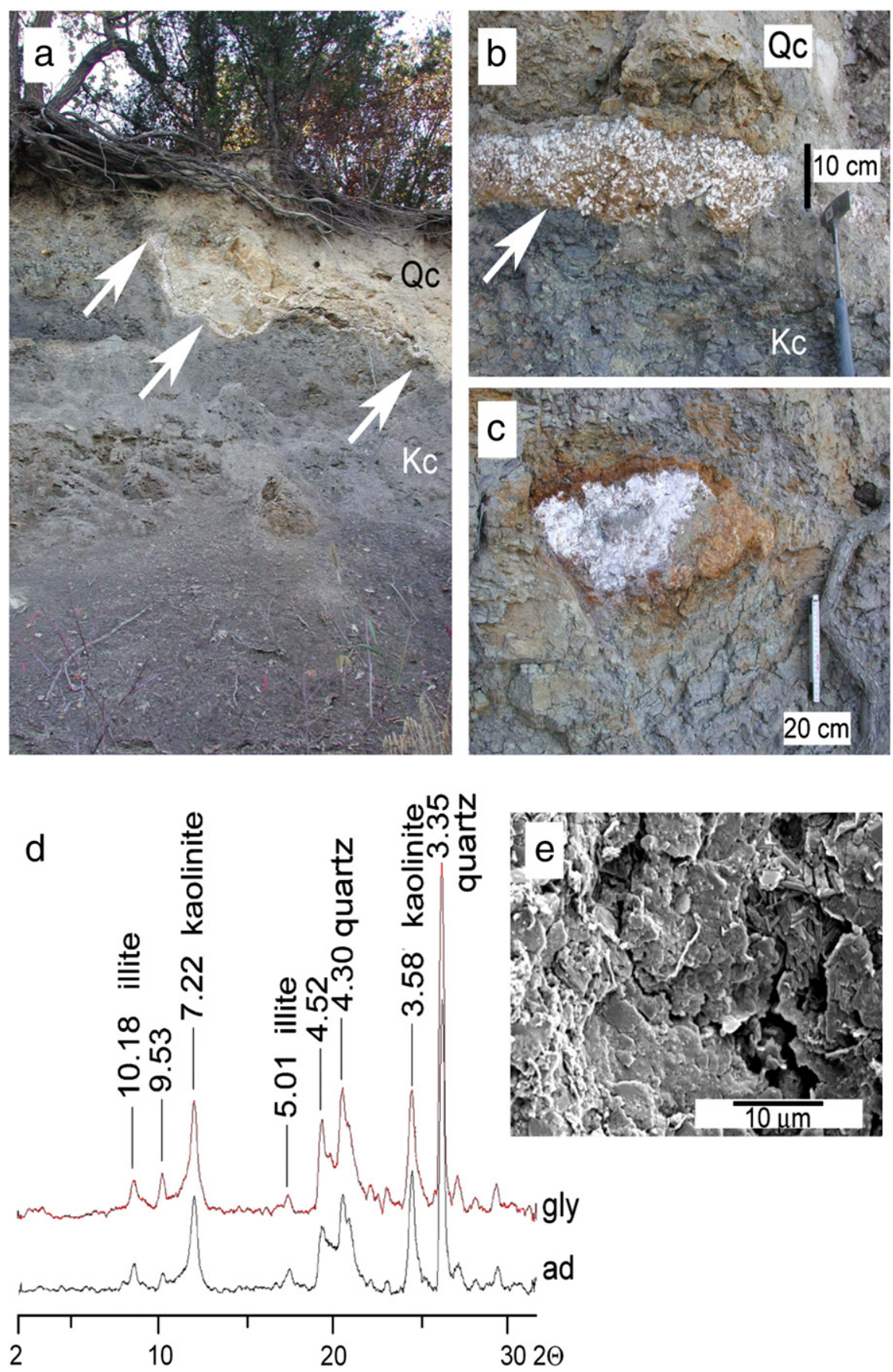

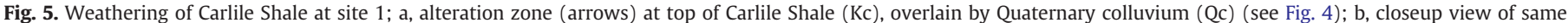

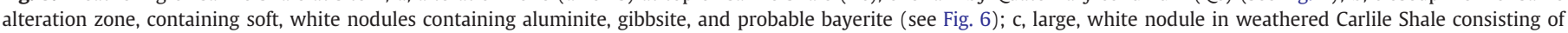

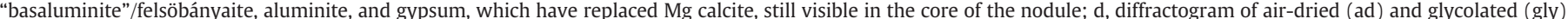

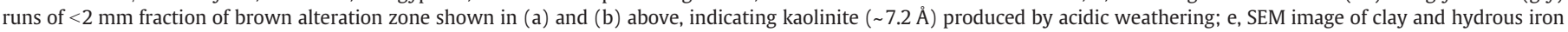
oxide-bearing matrix of same alteration zone.

Carlile Shale. The intact Carlile Shale here has been rotated slightly downslope by successive slumps (Fig. 4). White nodules and alteration features also appear deeper within the weathered Carlile Shale along a few, very large, subhorizontal fractures attributable previous mass movements. These small nodules are dominated by aluminite. X-ray diffractometry indicates that they also contain gibbsite and probable minor bayerite, as well as gypsum (Fig. 6). One diffractogram, for example, shows a prominent $\sim 2.22 \AA$ peak (Fig. 6a), which would be characteristic of bayerite, and which is not overlapped by any XRD peaks of aluminite, or for that matter gibbsite (cf. Rodgers et al., 1991). Peaks at $\sim 2.05 \AA$ and $\sim 4.30-4.40 \AA$ in the same diffractogram (Fig. 6a) correspond neither to aluminite nor to bayerite, and possibly represent peaks of gibbsite, the other major peaks of which would be obscured by the diffraction pattern of aluminite. Another sample yields a comparatively definitive diffraction pattern for gibbsite (Fig. 6b).

The slightly to moderately weathered shale below and around zones containing secondary minerals exhibits color changes (bleaching to $5 \mathrm{Y} 7 / 1$ light gray or $5 \mathrm{Y} 8 / 1$ white, for example), irregular 2.5 Y $6 / 8$ olive yellow banding; discrete, large secondary gypsum crystals and 5 to $20 \mathrm{~mm}$-thick sheets or veins of fibrous gypsum lining fractures (Fig. 2). It also shows coatings of pale yellow (2.5Y $8 / 4$ and $5 Y$ 8/3), brownish yellow (10YR 7/6) and yellow (10YR 6/6) jarosite and brownish yellow (10YR 6/6) hydrous iron oxides along fractures. 
a
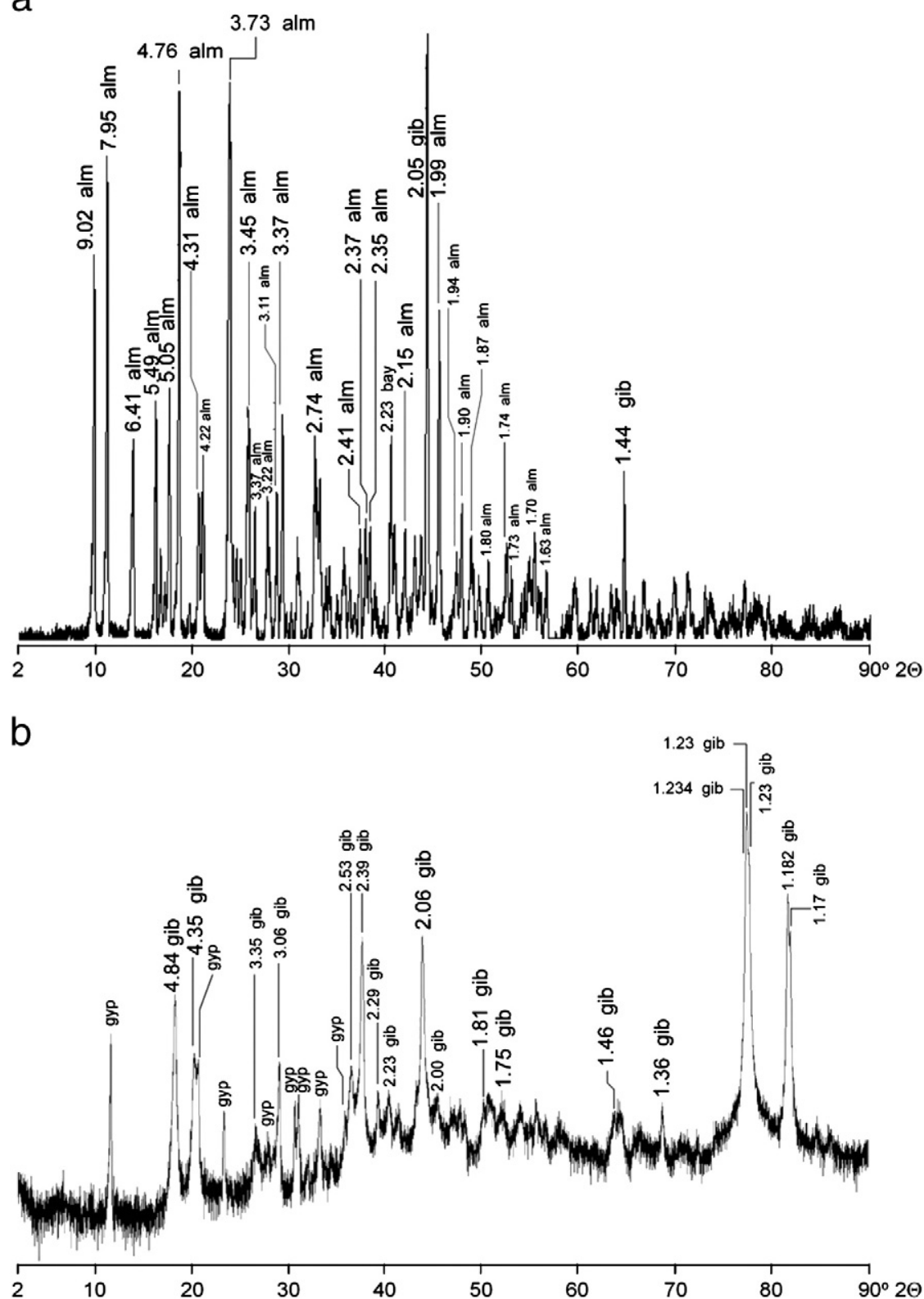

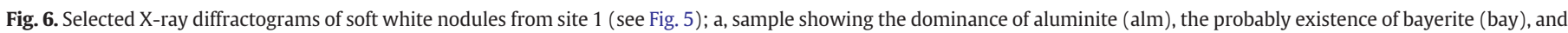
the possible existence of gibbsite (gib); b, sample dominated by gibbsite (gib) and gypsum (gyp). Values of "d" in Ångströms.

A few, large, weathered nodules, as much as $40 \mathrm{~cm}$ in diameter, appear in the weathered Carlile Shale below the main zone of alteration (Fig. 5c), and such nodules can also be found in debris that has been moved downslope by mass wasting. These large nodules consist of: (1) a thin $(2-3 \mathrm{~cm})$ cortex of earthy, poorly crystalline, yellow (10YR 7/8) hydrous iron oxide and small gypsum crystals; (2) a thick inner zone of very soft, earthy, finely crystalline, white $(\sim \mathrm{N} 8 / 0)$ material identified by XRD as "basaluminite"/felsöbányaite, aluminite, and gypsum; and (3) a core likewise containing "basaluminite"/ felsöbányaite, aluminite, and gypsum, but also containing irregular, subrounded masses of slightly harder, dark grayish brown and brownish yellow (10YR 4/2 and 6/8), fine-grained magnesium calcite. It appears that these nodules originally consisted entirely of magnesium calcite, and that this primary carbonate phase was replaced by secondary "basaluminite"/felsöbányaite, aluminite, and gypsum during surficial weathering (cf. Clayton, 1980).

In a subsidiary altered zone around a slip plane even deeper in the weathered Carlile Shale (Figs. 4, 5a), primary, rounded, 2 to $6 \mathrm{~cm}$ nodules of black (10YR 2/1) and dark grayish brown (10YR 4/2) fluorapatite and hydroxylapatite have fracture fills and exterior coatings of soft, white $(\sim \mathrm{N} 8 / 0)$ coatings consisting of gypsum and the rare $\mathrm{Al}$ phosphate-hydroxide vashegyite. Vashegyite is detectable in these nodules because of distinctive XRD peaks corresponding to $\mathrm{d}=\sim 11.1$ to $11.3 \AA$ (Fig. 3e), representing a 002 reflection (cf. Johan et al., 1983; Onac et al., 2006, Figs. 2). Most phosphatic nodules in the weathered Carlile Shale are completely enclosed by coatings, and in some of them the phosphatic part of the nodule has been almost completely replaced, except for a few, engulfed, subangular fragments in the center of the mass. In the latter cases, nodules consist dominantly of secondary gypsum, with only minor vashegyite and brownish hydronium jarosite. Under the SEM, vashegyite is most abundant in the outermost zone of coatings around phosphate nodules, and it is underlain by layers of microscopic, tabular and prismatic crystals of gypsum (Fig. 3c, d). Vashegyite crystals are very small, ranging in length from 4 to $6 \mu \mathrm{m}$ and in width from 2 to $3 \mu \mathrm{m}$, and have aspect ratios (length:width) of 1.8 to 2.1. They are 
distinctively tabular, angularly lozenge-shaped, and flattened on (001), with prominent \{110] faces (cf. Johan et al., 1983; Anthony et al., 2001-2005) (Fig. 3a-d). Very small crystals appear to be characteristic both of archived type specimens of the mineral (Johan et al., 1983) and of newly-discovered occurrences (Onac et al., 2006). In keeping with its "phyllophosphate" or sheet phosphate structure (sensu McConnell, 1974), crystals of vashegyite from site 1 appear in "books" or bundles consisting of a many tens of crystals. These bundles also form indistinct, whorl-like aggregates 13 to $18 \mu \mathrm{m}$ in diameter, which curve around central voids 2 to $3 \mu \mathrm{m}$ in diameter (Fig. 3b).

\subsection{Site 2: Volcano Hill or "Ionia Volcano", Dixon County, Nebraska}

Site $2\left(\sim 42^{\circ} 41^{\prime} 26^{\prime \prime} \mathrm{N}, 96^{\circ} 49^{\prime} 51^{\prime \prime} \mathrm{W}\right)$ is a high, east-facing natural cliff exposing the Carlile Shale overlain by Wisconsinan Peoria Loess (Figs. 7, 8). This site, so named because the locals mistook effects from the in-situ oxidation of iron sulfides as igneous activity (Threet, 1956; Smith, 1978), is one of the earliest-documented geologic heritage sites in the western USA, yet there is no comprehensive scientific account of it. Groundwater seepage from the cliff face is evidenced by these historical accounts. The highest (middle) part of the cliff face exhibits a $220 \mathrm{~cm}$-deep zone in the uppermost exposure of the Carlile Shale (Figs. 7a; 8a-b). This zone consists of as much as 20\% yellow (10YR 7/6 and 7/8) jarosite infillings and linings in vertical and horizontal fractures, as well as less-common discoidal bedding-plane-parallel nodules of soft jarosite approximately $1-6 \mathrm{~cm}$ in maximum diameter (Fig. 8b). Shale in this zone is bleached to light gray (10YR 7/1) around cores of gray (10YR 6/1), and it is also stained yellow (10YR 7/6 and 7/
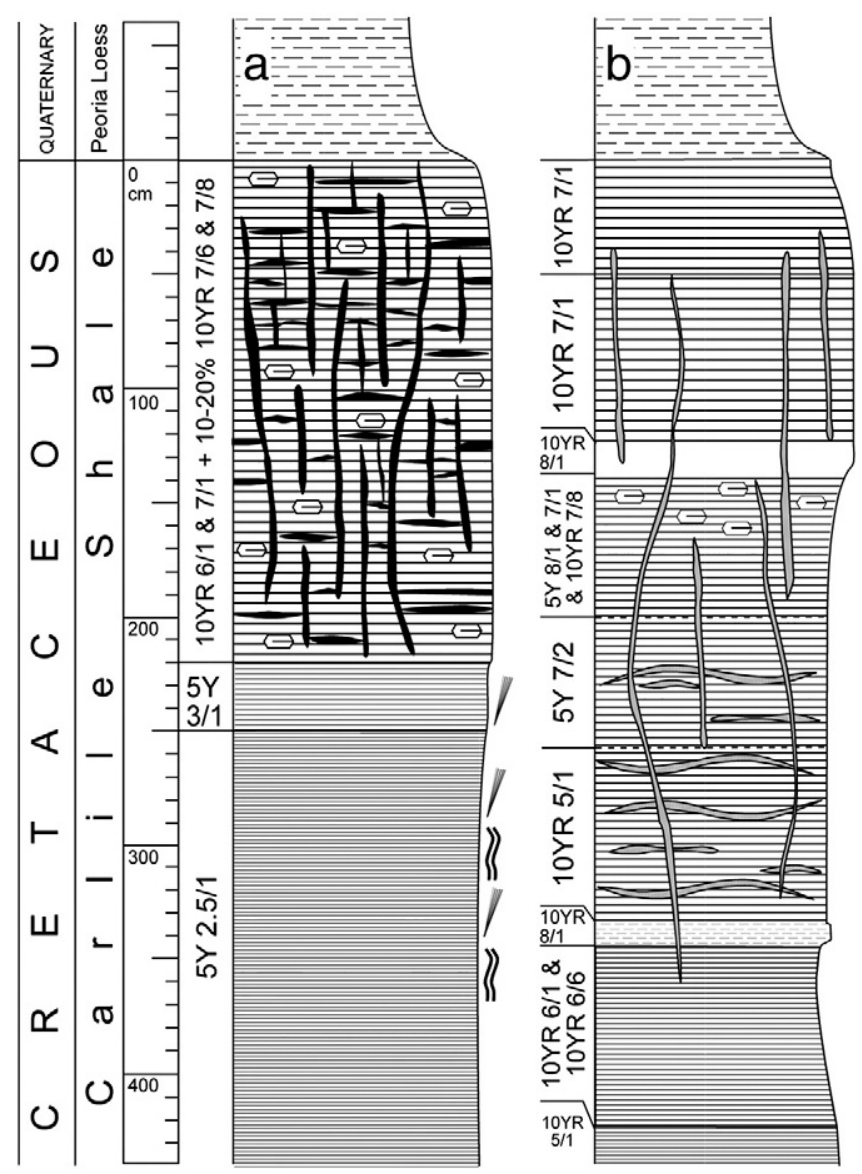

Fig. 7. Weathering profiles in Carlile Shale at site 2; a, at middle (highest part) of exposure; b, section downslope to north and downsection from "a". See Fig. 9 for symbol key.
8) around bedding planes in association with the accumulation of jarosite. These features contrast starkly with the very dark gray (5Y 3/ 1) to black (5Y 2.5/1) colors of relatively fresh, moist shale lower in the outcrop. About $2 \%$ of the volume of the jarosite-enriched weathering zone consists of large $(1-20 \mathrm{~cm})$ tabular pseudo-rhombohedral crystals (sensu Jafarzadeh and Burnham, 1992) of secondary selenite gypsum. Most of these crystals contain inclusions of weathered shale and many of them exhibit twinning; some show internal "ghost" crystal outlines under UV light. Microcrystalline efflorescences of gypsum are common in the lower part of the outcrop. Dark yellowish brown (10YR 4/4) ferric hydroxide stains are also common on fracture surfaces. Downslope to the north, secondary jarosite is less prominent, but still present, and gray shales have been bleached to white (5Y 8/1) by weathering (Fig. 7b).

In very weakly weathered shale, below the heavily-weathered zone of jarosite concentration, melanterite locally appears in efflorescences as bundles of fine $(<10 \mathrm{~mm})$, bluish, hairlike, capillary crystals near the surface of the outcrop along fractures and in recesses (Fig. 7a). Serial visits indicate that it is a transient phase compared to the persisting jarosite at the site, which appears in association with more complete weathering of the shale host rock. Halotrichite is also common locally as a very thin, white crust on the surface, also mostly in the very weakly weathered lower part of the outcrop (Fig. 7a).

Deeper in the Carlile Shale is a thin bentonite (Fig. 8c) that has been altered from the original smectite clay by acid weathering to kaolinite (Fig. 8d). Discrete beds of smectite bentonite are widely known to occur at this position within the Carlile Formation, and their appearance is very characteristic and therefore easily recognizable in the field (cf. Hattin, 1962).

\subsection{Site 3: Harlan County Reservoir, Harlan County, Nebraska}

Site $3\left(\sim 40^{\circ} 4^{\prime} 26^{\prime \prime} \mathrm{N}, 99^{\circ} 21^{\prime} 29^{\prime \prime} \mathrm{W}\right)$ is a series of low (8-10 m) cliffs exposed along the shore of Harlan County Reservoir (Figs. 1, 9, 10 ), which have been subjected to regular slumping and erosion since the lake was impounded over 50 years ago. These cliffs expose the lower Pierre Shale, which is overlain by Late Pleistocene to Holocene deposits of: (1) silty colluvium under a spur ridge truncated by shoreline erosion and, laterally, (2) sandy to silty alluvium under an eroded terrace of the Republican River. There are at least five calcite- and magnesium-calcite-cemented bentonitic beds within the exposed part of the Pierre Shale, and these beds weather in slight relief (Fig. 9). Grayish to brownish, moderately soft to hard, $2-5 \mathrm{~cm}$ ovoid nodules or lag pebbles of marine phosphate (fluorapatite) are associated with some of these beds (Fig. 9) are undergoing weathering just as the host shale is. Acid drainage in groundwater seepage was directly visible at site 3 prior to the onset of long-term drought conditions ca. 1999, and again as recently as July 2009 . Visible seepage is currently concentrated near the base of the cliff, although it could easily have occurred higher in the face in the recent past.

The Pierre Shale is very strongly weathered near the top of the outcrop and moderately to strongly weathered in a thick zone below, but it is only weakly moderately weathered near the base of the cliff line (Fig. 9). Its colors range from gray (2.5Y 5/1) where it is weakly weathered, to pale yellow (e.g., 5Y 8/3) and white (5Y 8/1) where it is strongly weathered (Fig. 9). The more heavily weathered parts of the Pierre Shale weather into lenticular masses between subhorizontal fracture planes that crosscut bedding (Fig. 10a). We speculate that the subhorizontal fractures may be related to stress release near the face of the outcrop, but they also have a clear relationship with weathering, in that the shale around them is oxidized to very pale brown (10YR 7/4) (Fig. 10a). The subhorizontal fractures also contain discontinuous, very thin $(\sim 1 \mathrm{~mm})$ sheets of selenite gypsum, and surficial crusts of yellow (2.5Y 7/4) jarosite appear on the exposed 

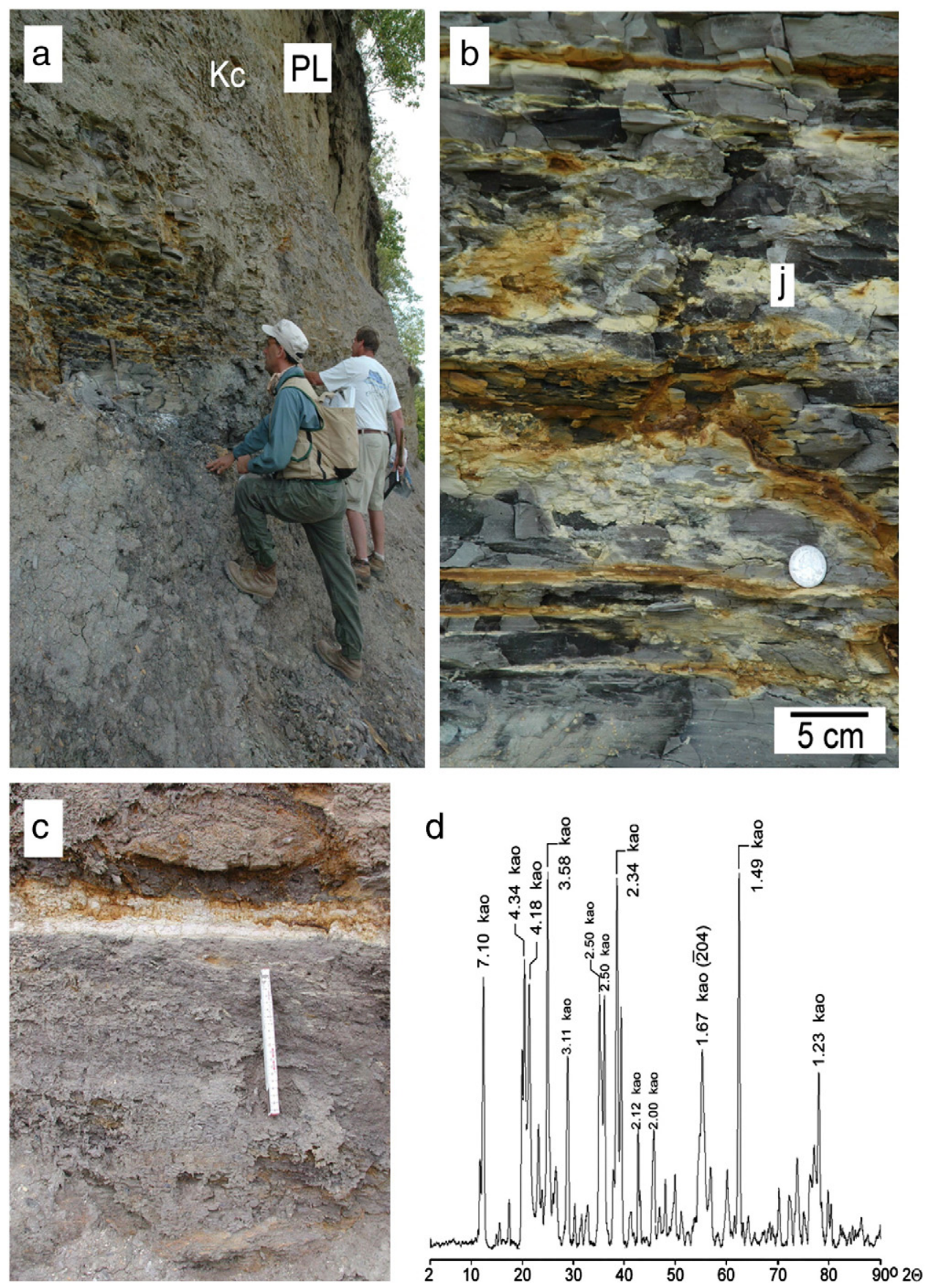

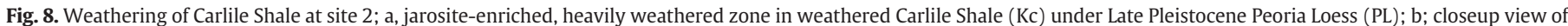

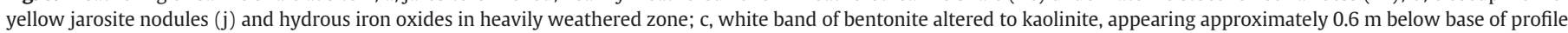
shown in Fig. 7b (20 cm scale); d, diffractogram of white band shown in (c). indicating nearly pure kaolinite (kao), values of "d" in Ångströms.

faces of lenticular masses (Fig. 10a). Measured pH levels of weathered shales at the site range from 3.6 to 3.7 .

Reddish yellow (7.5YR 6/6) to strong brown (7.5YR 5/6) hydrous iron oxide coatings, large sheets of centimeter-scale crystals of secondary gypsum, and yellow (5Y 8/6 and 8/8) crusts consisting of intergrown, flattened, and mammillate nodules of jarosite and hydronium jarosite appear along joints (i.e., vertical to subvertical fractures) in the shale. Discontinuous, horizontal sheets of prismatic crystals of secondary gypsum, usually $10 \mathrm{~mm}$ or less in thickness, are distributed throughout the upper, more heavily weathered, part of the exposure. Similar, 5 to $12 \mathrm{~mm}$-thick sheets of prismatic gypsum crystals are common within and around the bentonitic layers. These gypsum sheets are commonly bounded by yellow (5Y 8/6 and 8/8), mammillate crusts of irregular, intergrown, flattened jarosite nodules a few millimeters thick. More importantly, soft, white ( 10YR 8/1), spherical to ovoid, 5-40 mm nodules of alunite and "basaluminite"/ felsöbányaite appear within and around the thickest sheets of secondary gypsum that are associated with bentonitic beds (Figs. 10b, 11).

Vashegyite appears as dull, white powdery coatings with gypsum on the outer surfaces of weathered phosphate nodules (Fig. 3f). Vashegyite is readily distinguished in these samples by a distinctive $\sim 11.17$ Å peak in the diffractogram (Fig. 3e) and by crystal form (cf. Johan et al., 1983; Onac et al., 2006, Figs. 2, 4). The vashegyite crystals from site 3 are tabular, angularly lozenge-shaped, and flattened on (001), with prominent $\{110]$ faces (Johan et al., 1983; Anthony et al., 


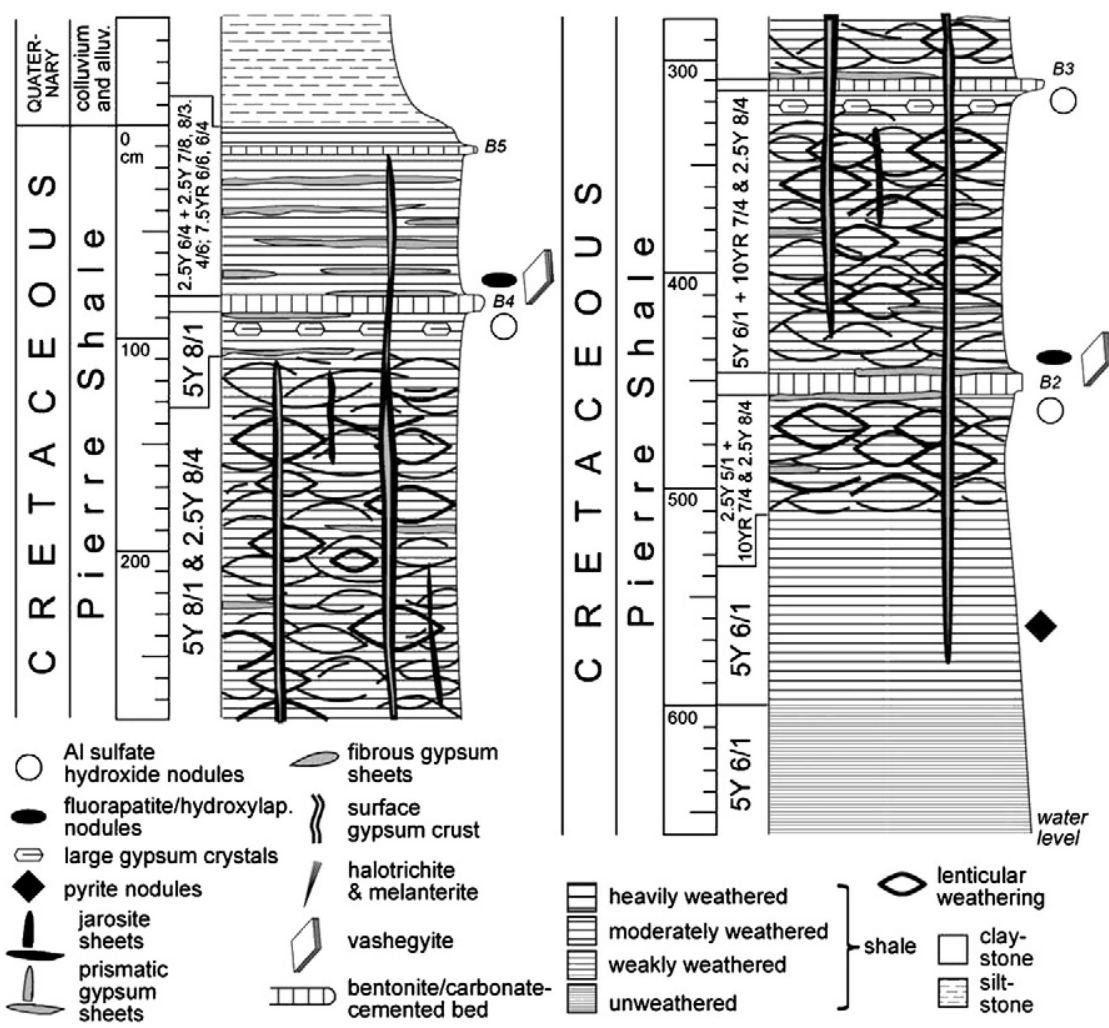

Fig. 9. Weathering in Pierre Shale at site 3.

2001-2005). Some of them show chevron-shaped "notches" parallel to $\{110\}$, which are interpreted as growth faces identical to features visible in the crystals figured by Onac et al. (2006), (Fig. 2d) from a Romanian cave. Similar to the occurrence of the mineral at site 1 , vashegyite crystals from site 3 (Fig. 3a) range in length from approximately 7 to $10 \mu \mathrm{m}$ and in width from approximately 3 to $6 \mu \mathrm{m}$, and they are approximately $1 \mu \mathrm{m}$ in thickness (cf. Johan et al., 1983 and Onac et al., 2006), and they have aspect ratios (length: width) of approximately 1.4 to 2.5 . Although no single crystal was perfectly oriented for measurement, the angles between adjacent $\{110\}$ faces in the crystals from site 3 are approximately 30 to $35^{\circ}$, an angular orientation roughly similar to that represented in one of the forms illustrated by Johan et al. (1983), (Fig. 1). Vashegyite crystals consist of conspicuous bundles of sheets (Fig. 3a), appearing at site 3 as stacks of perhaps 5 to 15 or more individual sheets, altogether totaling 3 to $9 \mu \mathrm{m}$ in thickness. XRD analyses indicate that the interiors of the vashegyite-hosting nodules from site 3 also contain secondary gypsum.

\section{Discussion}

\subsection{Occurrence of secondary minerals in context}

The Al-bearing minerals aluminite, alunite, bayerite, gibbsite, and vashegyite have never been described from Nebraska (cf. Pabian, 1993) or, to our knowledge, from any of multiple nearby states in the enclosing region of the USA. Joeckel et al. (2007), however, found minor "basaluminite"/felsöbányaite at another acidic weathering site in Nebraska, as did Tien (1968) in Kansas. Aluminite, alunite, "basaluminite"/felsöbányaite, and gibbsite are moderately common minerals worldwide in weathering and alteration environments, but bayerite is very rare (Rodgers et al., 1989, 1991; Dani et al., 2001), having been described from a very few low-temperature environments (e.g., Gedeon, 1956; Vernet, 1962; Naray-Szabo and Peter, 1967; Khorosheva, 1968; Wilmot and Young, 1985). Bayerite has been found together with gibbsite in nodules produced by deep weathering below the soil solum in one other occurrence, within karstic features (Wilmot and Young, 1985). Alunite occurs in a variety of alteration environments and forms across a very wide range of temperature, and although it occurs in low-temperature, near-surface, meteoricweathering settings (Dill, 2001), accounts of such are comparatively rare. Aluminite occurs generally in association with acid rock weathering and the past or present percolation of groundwater, and sometimes in karst settings (e.g., Martini et al., 1997; Polyak and Provencio, 1998; De Putter et al., 2000). “Basaluminite”/felsöbányaite, has been reported in clear association with such phenomena as past or ongoing acid rock weathering, karstification, major unconformities and hydrologic discontinuities, and the deeper percolation of groundwater (e.g., Hollingsworth and Bannister, 1950; Milton et al., 1955; Frondel, 1968; Tien, 1968; Mitchell, 1970; Gricius, 1971; Clayton, 1980; De Putter et al., 2000). Gibbsite appears in many soil and weathering environments, although typically in warmer and wetter climates than that of the study area.

Vashegyite is a particularly rare mineral, yet it has been described from environments as diverse as phosphate-bearing albitized pegmatites (Atencio and Coutinho, 2005), altered metamorphic rocks (Clinton, 1929), fractured cherts (Hausen, 1962; Milton et al., 1982), and altered phosphatic black shales (Van Tassel, 1985), but its most well-documented occurrences are in association with the acid leaching of bird or bat guano and the weathering of underlying clays or volcanic rocks in caves and rookeries (Vennum et al., 1994; Barczuk and Tatur, 2003; Onac et al., 2006). Thus, its occurrence in weathering profiles at our sites 1 and 3 can be considered generally similar to the last kind of occurrence, yet all but exceptional relative to accounts in the published literature

Hydronium jarosite, jarosite, and gypsum (Table 1), in comparison to some of the other minerals found in this study, are particularly common as secondary minerals in acid-weathering environments; halotrichite and melanterite are also commonly reported. Jarosite, halotrichite, and melanterite as well have previously been described 

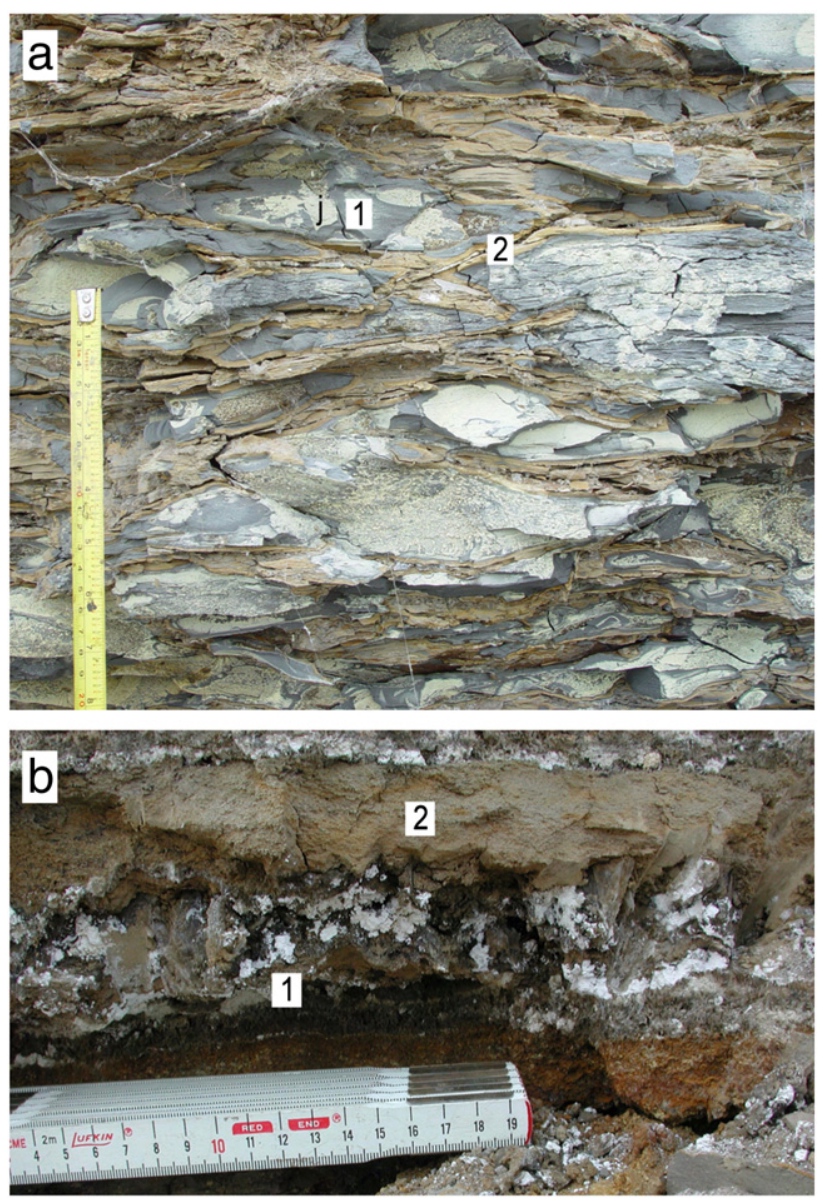

Fig. 10. Weathering of Pierre Shale at site 3; a, lenticular masses of gray (2.5Y 5/1), moderately to heavily weathered shale several centimeters in length (1) surrounded by very pale brown (10YR 7/4) oxidized shale (2), containing discontinuous, very thin $(\sim 1 \mathrm{~mm})$ sheets of selenite gypsum, and with surficial crusts of yellow (2.5Y 7/4) jarosite (j); scale in centimeters and inches; b, white alunite and "basaluminite" felsöbányaite nodules in thick sheets of prismatic selenite gypsum above and below (1) slightly resistant bentonite bed (2); scale in centimeters.

from Nebraska by Pabian (1993), but among these occurrences, only a single occurrence of halotrichite has previously been described in any detail (Joeckel et al., 2007).

There are significant differences between the suite of minerals described in this study and that described previously from other acid rock weathering sites on Cretaceous rocks in Nebraska. Joeckel et al. (2005) found the hydrated aluminum sulfate alunogen, and probably meta-alunogen as well (Table 1 ) from crusts/efflorescences at an acid rock drainage site on the Cretaceous Dakota Formation (Fig. 1b), but these minerals could not be identified in any mode of occurrence at the sites described in the present study. Aluminite, alunite, "basaluminite"/felsöbányaite, bayerite, gibbsite (and vashegyite as well), in comparison, were completely absent at the Dakota Formation localities described by Joeckel et al. (2005), whether in surface features, along fractures in weathered bedrock, or within the rock mass itself. A variety of hydrated iron sulfates described by Joeckel et al. (2005) were also absent at the sites discussed in the present paper. The iron sulfates hydronium jarosite and jarosite, which are nearly ubiquitous in acid sulfate soils and naturally-weathered sulfidic rocks, could be identified at all of the present study sites, but minerals of the jarosite subgroup were conspicuously absent in the mineral efflorescences and in fractures in the weathered Dakota Formation rocks studied by Joeckel et al. (2005). These mineralogical differences exist in conjunction with two obvious differences in site characteristics. First, the hydrated $\mathrm{Fe}$ and $\mathrm{Al}$ sulfates minerals described from the
Dakota Formation sites by Joeckel et al. (2005) occurred in surface crusts and efflorescences exclusively, whereas most of those described in the present study appear in or along joints or fractures, in discrete alteration zones, or as nodules within the rock mass. Second, the localities described by Joeckel et al. (2005) were roadcuts rather than natural exposures, and weathering processes had been at work there for mere decades, whereas the localities described in the present paper are natural exposures that must have been undergoing weathering at or near the land surface for centuries to millennia, after the Late Pleistocene.

\subsection{Weathering processes and secondary mineral assemblages}

The association of acid weathering following the oxidation of pyrite, percolation or discharge of groundwater, and the formation of secondary Al minerals, typically at or around a geologic contact, unconformity or geohydrologic discontinuity, is a documented, even if neither fully realized nor appreciated, geological theme (e.g., Ross et al., 1968; Sunderman and Beck, 1969; Clayton, 1980; De Putter et al., 2000).

The neoformed aluminous minerals identified in this study must have formed after from the release of Al by acid weathering solutions. Hydrous phyllosilicates in the host shales are the only significant aluminum-bearing minerals in the host shales, therefore they must be the source of Al. The reaction of acid sulfate solutions with hydrous phyllosilicates, particularly clay minerals, has been identified by several authors as the source of Al for the formation of minerals such as "basaluminite"/felsöbányaite and alunite in soils and other weathering environments where pyrite oxidation has occurred (Keller et al., 1967; Frondel, 1968; Adams and Hajek, 1978; Clayton, 1980; Khoury, 1987; Hassan and Baioumy, 2007). Furthermore, laboratory experiments by Shamshuddin et al. (1995) readily demonstrated that both jarosite and alunite could be precipitated from incubated samples of acid sulfate soil, that is, oxidized sulfidic material, when they were treated with $\mathrm{NaCl}$ and $\mathrm{KCl}$ solutions. Similarly, laboratory studies by Adams and Hajek (1978) showed that alunite will form after "basaluminite"/felsöbányaite if the ambient sulfate-bearing solutions contain $\mathrm{K}^{+}$, which could, in a natural setting like those described herein, be liberated by the breakdown of hydrous phyllosilicates such as illite or illite/smectite, common clay-fraction constituent in sedimentary rocks (Keller et al., 1967; Hassan and Baioumy, 2007), and specifically in Cretaceous shales in the western interior of USA (e.g., Tourtelot et al., 1960; Schultz, 1978). Aluminite formation in low-temperature settings has also been attributed to the natural reaction of acidic sulfate solutions with clays, particularly kaolinite (e.g., Polyak and Provencio, 1998). Ross et al. (1968) suggested that aluminite could be the antecedent of alunite in weathering sedimentary rocks at or near the land surface, but they did not substantiate this comment. Gibbsite can also have precipitated directly from acidic sulfate solutions under certain conditions. Adams and Hajek (1978), for example, found that gibbsite will directly precipitate, together with alunite and "basaluminite"/felsöbányaite, from sulfate solutions if the ratio $\mathrm{SO}_{4}^{2-} / \mathrm{Al}^{3+}$ is low and $\mathrm{OH}^{-} / \mathrm{Al}^{3+}$ is high. These observations suggest that the molar ratios of weathering solutions may have slightly differed at site 1 , where gibbsite has been identified, relative to the other sites, where no gibbsite was found. Given that Al was released into migrating sulfate solutions by acid weathering, vashegyite at sites 1 and 3 must originate from the localized reaction of such solutions with fluorapatite and hydroxylapatite in primary sedimentary nodules.

Our documentation of the abnormal occurrence of kaolinite as a weathering product in otherwise smectitic sedimentary rocks is of equal importance to the aforementioned assemblage of sulfates, hydroxide, and phosphate minerals. In this respect, silicate weathering in zones of acid weathering has far exceeded the intensity of 

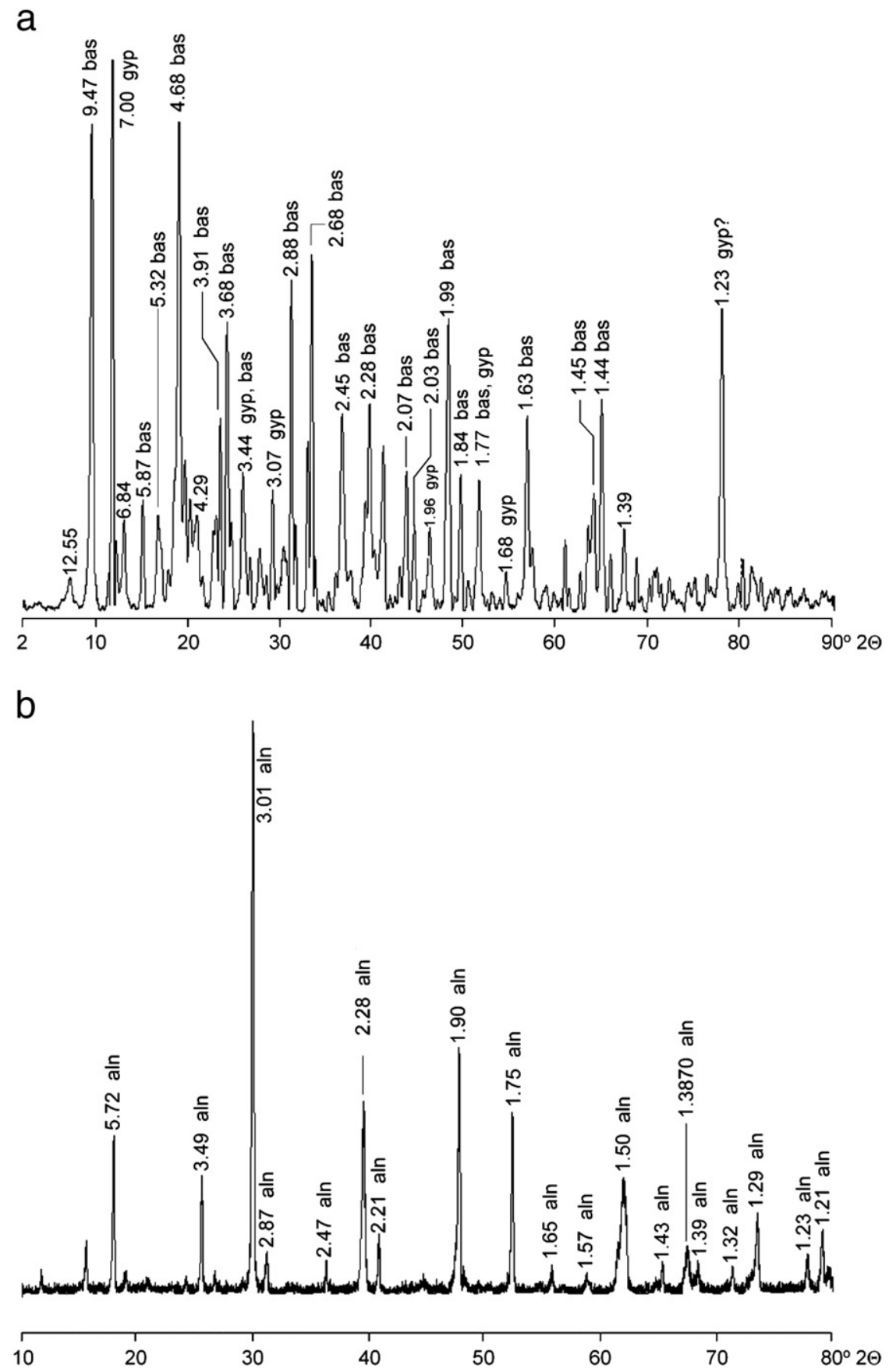

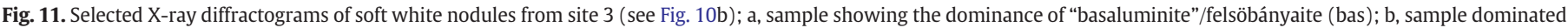
by alunite (aln). Values of "d" in Ångströms.

weathering processes in any extant soils in the overall study area. As apparently out of place as this intense localized weathering is in the context of much weaker regional regimes of pedogenic weathering, there are several precedents in the published literature for the occurrence for the aluminum-bearing minerals in bedrock weathering environments.

Documented occurrences of secondary aluminous minerals in association with low-temperature acidic weathering in sedimentary rocks typically involve both a pyrite-bearing source rock that weathers to create acidic sulfate solutions and a carbonate host rock, or some other source or carbonate such as authigenic nodules, that reacted with migrating acidic sulfate solutions so as to elevate solution $\mathrm{pH}$ and prompt the precipitation of aluminous minerals (e.g.,
Clayton, 1980; Wilmot and Young, 1985; Ambers and Murray, 1995). Our results differ from typical examples of this association (e.g., Wilmot and Young, 1985; Ambers and Murray, 1995) in that: (1) the occurrences of aluminous minerals at site 1 are either directly below in-situ limestone, in direct association with limestone-derived calcareous colluvium, or around magnesium carbonate nodules (cf. Clayton, 1980), rather than within karst depressions or atop a limestone; and (2) there are no limestones at sites 2 and 3, although the bentonites hosting secondary aluminous minerals at site 3 contain calcite and magnesium calcite. Nonetheless, there are still identifiable carbonate phases at sites 1 and 3 with which acidic solutions could react, and concentrations of secondary aluminous minerals tend to occur in very close proximity to these phases. 
a

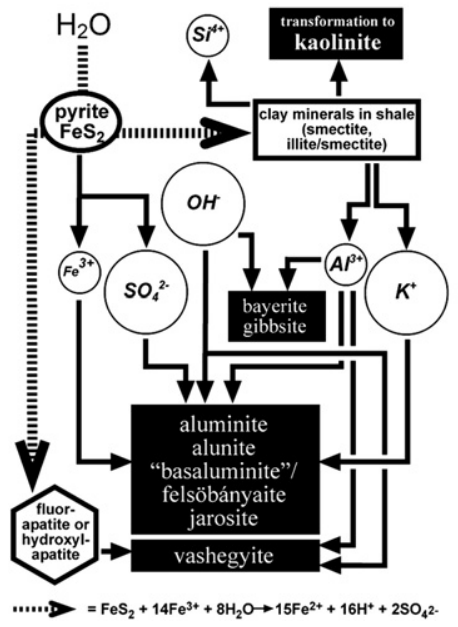

b

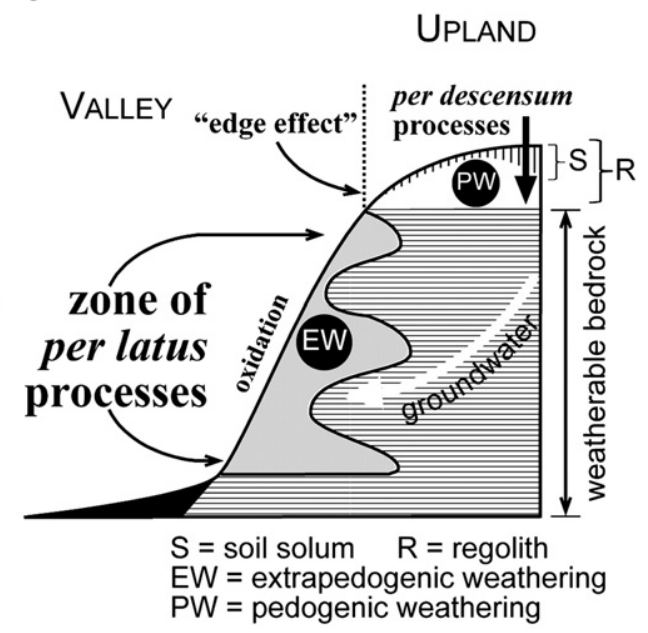

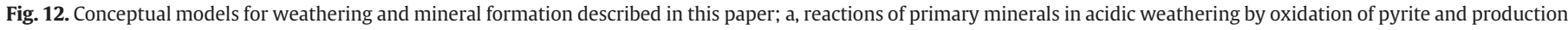

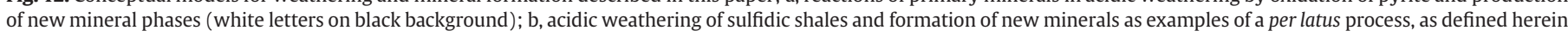
for sites $1-3$.

\section{Conclusions}

5.1. Products of acidic weathering in reactive shales and their implications

Acid weathering from the oxidation of pyrite has led to the chemical attack of hydrous phyllosilicates and phosphates in host rocks to produce the Al-bearing secondary minerals described herein (Fig. 12a); weathering at site 1 has even produced aluminum hydroxides (gibbsite and, probably bayerite as well), which are usually thought of as end-members in a generalized long-term weathering sequences of terrestrial silicate mineral assemblages. Abnormally abundant kaolinite in the altered zone at site 1 also indicates the weathering of hydrous phyllosilicates in the host shales. In contrast, kaolinite produced exclusively by in-situ by weathering is either very rare or, more likely, completely non-existent in any known surface soil in the enclosing region.

The results presented herein refute the widely-held, but largely unarticulated, presumption that rock weathering of any kind in the subhumid, mid-latitude, continental-climate plains interior of the USA is inconsequential and does not lead to major mineralogical changes. In the widespread, reactive, sulfidic Cretaceous epeiricmarine shales that underlie much of the interior of North America (Gautier, 1986; Arthur and Sageman, 1994), in glacial tills and other sediments derived from them, or in soils developed on any of these materials, some degree of acidic weathering is likely to be common (cf. Pawluk and Dudas, 1978; Mermut et al., 1985; Mermut and Arshad, 1987; Ross et al., 1988), therefore geologists and soil scientists should be aware of the phenomenon.

This study also leads to more specific conclusions about acidic weathering regimes and mineral assemblages. Minerals such as alunogen and meta-alunogen, as well as certain hydrated ironbearing sulfate minerals (e.g., copiapite, hohmannite, and metahohmannite) probably are more likely to appear in settings where pyrite oxidation is in its early stages and can proceed rapidly, such as manmade acid rock drainage settings such as mines and roadcuts (cf. Joeckel et al., 2005). Alunite, aluminite, and some of the other minerals associated with them appear to reflect longer-term weathering in natural environments under the present climatic regime in the study area. The differential occurrence of aluminumbearing secondary minerals in other settings (e.g., Hall et al., 2003; Buckby et al., 2003) lends general support the notion that different minerals (e.g., alunogen vs. alunite) tend to form in different environments of weathering (e.g., surface efflorescences produced rapidly by surface evaporation vs. crystallization within fractures or a rock mass). Similarly, compared to other sites in Nebraska described by Joeckel et al. (2005) and Joeckel et al. (2007), the surface efflorescences/crusts of the Fe-bearing sulfates melanterite and halotrichite described in the weakly weathered part of the Carlile Shale at site 2 represent an precursor stage of natural weathering relative to the overlying, more heavily weathered zone that is enriched in jarosite, but which lacks melanterite and halotrichite.

The kind of weathering that we describe leads also to the concentration, storage, and potential release of acidity, metals (particularly $\mathrm{Al}$ ), and other potentially problematic elements (e.g., As, Mo, Se, and U" see Tourtelot et al., 1960), as well as dramatic changes in the minerals that exist near-surface settings that will come into contact with ground and surface waters. Thus, the potential for widespread acidic weathering of pyrite-bearing Cretaceous sedimentary rocks, whether by per latus or per descensum processes, bears myriad potential effects that are associated with the formation of diverse new minerals. Such weathering can change bulk rock chemical and physical properties; influence the evolution of soils, surface waters, and ground waters; impact local environmental chemistry and microbial diversity; and affect road building, mass movement remediation, and waste disposal (e.g., Ivarson et al., 1979; Eberlin, 1985; Mermut and Arshad, 1987; Michel and van Everdingen, 1987; De Putter et al., 2000; Jambor et al., 2000; Daniels and Orndroff, 2003; Hammarstrom et al., 2003; Fanning et al., 2004; Joeckel et al., 2005; Darmody et al., 2007; Ji et al., 2007; Shand and Degens, 2008; Long et al., 2009). In the case of the American Great Plains, and large parts of adjacent regions, these aspects need to be considered as a matter of course for the first time.

The discovery of comparatively unique (in a regional context) products of natural acidic weathering also prompt a re-evaluation of existing paradigms for rock weathering relative to climatic conditions. The full range of mineral transformations and mineral neoformation through acid weathering in the study region is unknown, and without doubt includes a diversity of additional mineral phases whose occurrences will shed additional light on these processes. Additional studies will be needed to fully understand the production of secondary minerals in acidic weathering environments along major drainages and their environmental effects, including the long-term evolution of groundwater chemistry. 


\subsection{Concepts of extrapedogenic and per latus processes}

The phenomena we have described are only loosely connected with local land-surface and pedogenic (sensu stricto) processes. They occur phenomenologically outside of association with any extant soil solum, making them "extrapedogenic" (Fig. 12b), even though overall the soil solum and whole regolith need to be considered as interacting parts of a larger natural system (e.g., Tandarich et al., 1994). Unlike more widely-appreciated forms of rock weathering, pyrite oxidation at our sites has not produced a continuous and uniform blanket of material under the modern land surface. Rather, its strongest effects appear to be limited to valley walls (Fig. 12b), and secondary minerals are concentrated at outcrop faces. The main valley-side sites of acidic weathering that we describe stand out as geographically-limited foci of comparatively intense geochemical change at the edges of major geomorphic features (i.e., the upland-valley transition). Such a setting effectively represents an "edge effect" reminiscent of both natural and manmade phenomena described at various scales in soil landscapes, primarily with respect to the concentration of iron oxides and hydrous oxides (Daniels and Gamble, 1967; Daniels et al., 1975; Hayes and Vepraskas, 2000; Phillips, 2000; Vaughan et al., 2008) (Fig. 12b).

A concept of per latus processes (Fig. 12b), as opposed to per descensum and per ascensum ones, should be espoused in order to achieve a fuller understanding of the soil-regolith-groundwater system (cf. Schoeneberger and Wysocki, 2005), particularly in cases of acid-weathering bedrock. The concept of per latus weathering enriches the entrenched and potentially misleading image of weathering as a largely vadose phenomenon involving mostly per descensum processes operating in a coherent continuum from the land surface downward.

\section{Acknowledgements}

This research was made possible by a permit from the U.S. National Park Service, Missouri National Recreational River, for which the authors are grateful.

\section{References}

Adams, F., Hajek, B.F., 1978. Effects of solution sulfate, hydroxide and potassium concentrations on the crystallization of alunite, basaluminite, and gibbsite from dilute aluminum solutions. Soil Sci. 126, 169-173.

Ambers, C.P., Murray, H.H., 1995. The role of carbonate bedrock in the formation of Indianaite halloysitic clays. Ind. Geol. Surv. Bull. 65, 1-29.

Anthony, J.W., Bideaux, R.A., Bladh, K.W., Nichols, M.C., 2001-2005. Handbook of Mineralogy (website). Mineralogical Society of America. http://www.handbookofmineralogy.org/. URL.

Arthur, M.A., Sageman, B.B., 1994. Marine black shales: depositional mechanisms and environments of ancient deposits. Ann. Rev. Earth Plan. Sci. 22, 499-551.

Atencio, D., Coutinho, J.M.V., 2005. Roscherite-group minerals from Brazil. Axis 1, 1-18

Barczuk, A., Tatur, A., 2003. Biogenic phosphate and sulphate minerals in the soils of Antarctic peninsula. Pol. Tow. Mineralog. Pr. Specjalne 23, 41-43.

Blowes, D.W., Ptacek, C.J., Jambor, J.L., Weisner, C.G., 2004. The geochemistry of acid mine drainage. In: Holland, H.D., Turekian, K.K., Holland, H.D. (Eds.), Treatise on Geochemistry, 9. Elsevier, Oxford, pp. 149-204.

Buckby, T., Black, S., Coleman, M.L., Hodson, M.E., 2003. Fe-sulphate rich evaporative mineral precipitates from the Río Tinto, southwest Spain. Min. Mag. 67, 263-278.

Clayton, T., 1980. Hydrobasaluminite and basaluminite from Chickerell. Dorset. Min. Mag. 43, 931-937.

Clinton, H.G., 1929. Vashegyite and barrandite in Nevada. Am. Min. 14, 434-436.

Condra, G.E., Reed, E.C., 1959. The geological section of Nebraska. Nebraska Geological Survey Bulletin 14A. Conservation and Survey Division, Univ. of Nebraska, Lincoln, Nebraska, pp. 1-82.

Dani, N., Luiz Laquintinie Formoso, M., Decarreau, A., Meunier, A., 2001. Nordstrandite in bauxite derived from phonolite, Lages, Santa Catarine, Brazil. Clays Clay Min. 49, $216-226$.

Daniels, R.B., Gamble, E.E., 1967. The edge effect in some Ultisols in the North Carolina Coastal Plain. Geoderma 1, 117-124.

Daniels, W.L., Orndroff, Z.W., 2003. Acid rock drainage from highway and construction activities in Virginia, USA. In: Farrell, T., Taylor, G. (Eds.), Proceedings, of the Sixth International Conference on Acid Rock Drainage (ICARD), pp. 479-487.
Daniels, R.B., Gamble, E.E., Buol, S.W., Bailey, H.H., 1975. Free iron sources in an AquultUdult sequence from North Carolina. Soil Sci. Soc. Am. Proc. 39, 335-340.

Darmody, R.G., Thorn, C.E., Dixon, J.C., 2007. Pyrite-enhanced chemical weathering in Kärkevagge, Swedish Lapland. Geol. Soc. Am. Bull. 119, 1477-1485.

De Putter, T., Bernard, A., Perruchot, A., Nicaise, D., Dupuis, C., 2000. Low-temperature acid weathering in Newhaven, Sussex, United Kingdom, and its application to theoretical modeling in radioactive waste-disposal sites. Clays Clay Min. 48, 238-246.

Dill, H.G., 2001. The geology of aluminium phosphates and sulphates of the alunite group minerals: a review. Earth Sci. Rev. 53, 35-93.

Eberlin, J.E., 1985. Chemical weathering and mechanical properties of the Carlile Formation at Igloo, South Dakota. Unpublished M.S. Thesis, South Dakota School of Mines and Technology, Rapid City, South Dakota.

Fanning, D.S., Coppock, C., Orndorff, Z.W., Daniels, W.L., Rabenhorst, M.C., 2004. Upland acid sulfate soils from construction of new Stafford County, Virginia, USA, airport. Aus. J. Soil Res. 42, 527-536.

Farkas, L., Pertlik, F., 1997. Crystal structure determinations of felsöbányaite and basaluminite, $\mathrm{Al}_{4}\left(\mathrm{SO}_{4}\right)(\mathrm{OH})_{10}$. Acta Min. Petrogr. Szeged 38, 5-15.

Frondel, C.J., 1968. Meta-aluminite, a new mineral from Temple Mountain. Utah. Am. Min. 53, 717-721.

Gautier, D.L., 1986. Cretaceous shales from the western interior of North America: sulfur/carbon ratios and sulfur-isotope composition. Geology 14, 225-228.

Gedeon, T.G., 1956. Bayerite in Hungarian bauxite. Acta Geol. Acad. Sci. Hung. 4, 95-105.

Gricius, A., 1971. Basaluminite in Iowa. Earth Sci. 24, 301-303.

Hall, A.J., Fallick, A.E., Perdikatsis, V., Photos-Jones, E., 2003. A model for the origin of Alrich efflorescences near fumaroles, Melos, Greece: enhanced weathering in a geothermal setting. Min. Mag. 67, 363-379.

Hammarstrom, J.M., Seal II, R.R., Meier, A.L., Jackson, J.C., 2003. Weathering of sulfidic and copper waste: secondary minerals and metal cycling in Great Smoky Mountains National Park, Tennessee, and North Carolina. USA. Env. Geol. 45, 35-57.

Hassan, M., Baioumy, H., 2007. Characterization and origin of alunite in the El-Gideda iron miner (Egypt). Per. Mineral. 76, 11-24.

Hattin, D.E., 1962. Stratigraphy of the Carlile Shale (Upper Cretaceous) in Kansas. Kans. Geol. Surv. Bull. 156155 p.

Hausen, D.M., 1962. Schoderite, a new phosphovanadate mineral from Nevada. Am. Mineral. 47, 637-650.

Hayes Jr., W.A., Vepraskas, M.J., 2000. Morphological changes in soils produced when hydrology is altered by ditching. Soil Sci. Soc. Am. J. 64, 1893-1904.

Hollingsworth, S.E., Bannister, F.A., 1950. Basaluminite and hydrobasaluminite, two new minerals from Northamptonshire. Min. Mag. 29, 1-17.

International Centre for Diffraction Data, 2001. Powder Diffraction File. Data Sets 1-51 plus 70-89. Release (CD-ROM). International Centre for Diffraction Data, Newtown Square, Pennsylvania.

Ivarson, K.C., Ross, G.J., Miles, N.M., 1979. The microbial crystallization of basic sulfates. II. Crystallization in the presence of potassium-, ammonium- and sodium salts. Soil Sci. Soc. Am. J. 43, 908-912.

Jafarzadeh, A.A., Burnham, C.P., 1992. Gypsum crystals in soils. Eur. J. Soil Sci. 43, 409-420.

Jambor, J.L., Grew, E.S., Roberts, A.C., 1998. New mineral names. Am. Mineral. 81, 1347-1352.

Jambor, J.L., Nordstrom, D.K., Alpers, C.N., 2000. Metal-sulfate salts from sulfide mineral oxidation. In: Alpers, C.N., Jambor, J.L., Nordstrom, D.K. (Eds.), Sulfate Minerals: Crystallography, Geochemistry, and Environmental Significance: Rev. Mineral. Geochem., 40, pp. 303-350.

Ji, S.W., Cheong, Y.W., Yim, G.J., 2007. ARD generation and corrosion potential of exposed roadside rockmass at Boeun and Mujoo, South Korea. Environ. Geol. 100, 1033-1043.

Joeckel, R.M., Ang Clement, B.J., VanFleet Bates, L.R., 2005. Sulfate mineral crusts from pyrite weathering and acid rock drainage in the Dakota Formation and Graneros Shale, Jefferson County. Nebraska. Chem. Geol. 215, 433-452.

Joeckel, R.M., Wally, K.D., Fischbein, S.A., Hanson, P.R., 2007. Sulfate mineral paragenesis in Pennsylvanian rocks and the occurrence of slavikite in Nebraska. Great Plains Res. 17, 17-33.

Johan, Z., Slansky, E., Povondra, P., 1983. Vashegyite, a sheet aluminum phosphate: new data. Can. Mineral. 21, 489-498.

Keller, W.D., Gentile, R.J., Reesman, A.L., 1967. Allophane and Na-rich alunite from kaolinitic nodules in shale. J. Sed. Pet. 37, 215-220.

Khorosheva, D.P., 1968. Bayerite from the bauxite horizon of the middle Dnieper region. Dok. Akad. Nauk SSR 182, 434-436.

Khoury, H.N., 1987. Alunite from Jordan. Neues Jb Mineral. Monats. 1987, 426-432.

Long, D.T., Lyons, W.B., Hines, M.E., 2009. Influence of hydrogeology, microbiology and landscape history on the geochemistry of acid hypersaline waters, N.W. Victoria. Appl. Geochem. 24, 285-296.

Martini, J.E.J., Wipplinger, P.E., Moen, H.F.G., 1997. Mbobo Mkulu Cave, South Africa, In: Hill, C.A. (Ed.), Cave Minerals of the World, second ed. National Speleological Society, Huntsville, Alabama, pp. 336-339.

McConnell, D., 1974. Are vashegyite and kingite hydrous aluminum phyllophosphates with kaolinite-type structures? Min. Mag. 39, 802-806.

Mermut, A.R., Arshad, M.A., 1987. Significance of sulfide oxidation and soil salinization in southern Saskatchewan. Soil Sci. Soc. Am. J. 51, 247-251.

Mermut, A.R., Curtin, D., Rostad, H.P.W., 1985. Micromorphological and submicroscopical features relatd to pyrite oxidation in an inland marine shale from east central Saskatchewan. Soil Sci. Soc. Am. J. 49, 256-261.

Michel, F.A., van Everdingen, R.O., 1987. Formation of a jarosite deposit on Cretaceous Shales in the Fort Norman area, Northwest Territories. Can. Mineral. 25, 221-226. 
Milton, C., Conant, L.C., Swanson, V.E., 1955. Sub-Chattanooga residuum in Tennessee and Kentucky. Geol. Soc. Am. Bull. 66, 805-810.

Milton, C., Dwornik, E.J., Marinenko, J., 1982. Vashegyite from Nevada and "palfevite" (= richmondite) from Nevada and from Arkansas (= kingite). In: McFarland III, J.D. (Ed.), Contributions to the Geology of Arkansas, pt. 1: Arkansas Geological Comm. Misc. Publ., 18 v. 1, pp. 53-62.

Mitchell, R.S., 1970. An occurrence of basaluminite in Maryland. Min. Rec. 1, 127-128.

Munsell Color, 1998. Munsell Soil Color Charts. Munsell Color GretagMacbeth, New Windsor, New York.

Naray-Szabo, I., Peter, E., 1967. Nachweis von Nordstrandit und Bayerit in ungarischen Ziegeltonen. Acta Geol. Acad. Scie. Hung. 11, 375-377.

Nordstrom, D.K., Alpers, C.N., 1999. Geochemistry of acid mine waters. Rev. Econ. Geol. 6 A, 133-160.

Onac, B.P., Zaharia, L., Kerns, J., Vereş, D., 2006. Vashegyite from Gaura cu Musc Cave (Locvei Mountains, Romania): a new and rare phosphate occurrence. Int. J. Speleo. $35,67-73$.

Pabian, R.K., 1993. The Minerals and Gemstones of Nebraska. Edu. Circ. No. 2. Cons. and Surv. Div., Inst. Agri. and Nat. Res. Univ. Nebraska-Lincoln.

Pawluk, S., Dudas, M., 1978. Reorganization of soil materials in the genesis of an acid Luvisolic soil of the Peace River region, Alberta. Can. J. Soil Sci. 58, 208-220.

Phillips, J.D., 2000. Rapid development of ferricretes on a subtropical valley side slope. Geog. Ann. 82, 69-78.

Polyak, V.J., Provencio, P., 1998. Hydrobasaluminite and aluminite in caves of the Guadalupe Mountains, New Mexico. J. Cave Karst Stud. 60, 51-57.

Rodgers, K.A., Gregory, M.R., Cooney, R.P., 1989. Bayerite $(\mathrm{Al}(\mathrm{OH}))_{3}$, from Raoul Island, Kermadec Group, South Pacific. Clay Miner. 24, 531-538.

Rodgers, K.A., Gregory, M.R., Cooney, R.P., 1991. Bayerite, nordstrandite, gibbsite, brucite, and pseudoboehmite in discharged caustic waters, Campbell Island, Southwest Pacific. Clays Clay Min. 39, 103-107.

Ross, C.S., Bergquist, H.R., Monroe, W.H., Fahey, J.J., Ross, M., 1968. Natroalunite in Upper Cretaceous sedimentary rocks, north-central Texas. J. Sed. Pet. 38, 1155-1165.

Ross, G.J., Eilers, R.G., Ivarson, K.C., 1988. Influence of acid sulfate weathering on chemical and mineralogical properties of an acid sulfate soil of Manitoba. Can. J. Soil Sci. 68, 629-644.

Schoeneberger, P.J., Wysocki, D.A., 2005. Hydrology of soils and deep regolith: a nexus between soil geography, ecosystems, and land management. Geoderma 126, 117-128.
Schultz, L.G., 1978. Mixed-layer clay in the Pierre Shale and equivalent rocks, northern Great Plains region. U.S. Geol. Survey. Prof. Paper 1064A, pp. 1-28.

Shamshuddin, J., Jamilah, I., Ogunwale, J.A., 1995. Formation of hydroxyl-sulfates from pyrite in coastal acid sulfate soil environments in Malaysia. Comm. Soil Sci. Plant Anal. 26, 2769-2782.

Avon catchment acidic groundwater-geochemical risk assessment. In: Shand, P., Degens, B. (Eds.), CRC LEME Open File Report 191.

Smith, G., 1978. Mt Ionia: Nebraska's volcano. Earth Sci. 31, 112-114.

Sunderman, J.A., Beck, C.W., 1969. Hydrobasaluminite from shoals. Indiana. Am. Mineral. 54, 1363-1373.

Tandarich, J.P., Darmody, R.G., Follmer, L.R., 1994. The pedo-weathering profile: a paradigm for whole-regolith pedology in the glaciated midcontinental United States of America. In: Cremeens, D.I., Brown, R.B., Huddleston, J.H. (Eds.), Whole Regolith Petrology. SSSA Spec. Pub No. 34. Soil Science Society of America, Madison, Wisconsin, pp. 97-117.

Threet, R.L., 1956. Nebraska's volcano. Nat. Mag. 49, 129-130.

Tien, Pei-Lin, 1968. Hydrobasaluminite and basaluminite in Cabaniss Formation (Middle Pennsylvanian), southeastern Kansas. Am. Mineral. 53, 722-732.

Tourtelot, H.A., Schultz, L., Leonard, G., Gill, J.G., 1960. Stratigraphic variations in mineralogy and chemical composition of the Pierre Shale in South Dakota and adjacent parts of North Dakota, Nebraska, Wyoming,a nd Montana. U.S. Geol. Surv. Prof. Paper 205B, pp. B447-B452.

Van Tassel, R., 1985. Mineraux phosphates secondaires (vashegyite, destinezite, wavellite, crandallite, phosphate de fer) a Haut-le-Wastia, Province de Namur (Belgique). Bull. Soc. Belge Geo. 94, 19-27.

Vaughan, R.E., Needelman, B.A., Kleinman, P.J.A., Rabenhorst, M.C., 2008. Morphology and characterizationof ditch soils at an Atlantic Coastal Plain Farm. Soil Sci. Soc. Am. J. 72, 660-669.

Vennum, W., Dunning, J., Leu, R., Anderson, B., Bergk, K., Boyce, R., 1994. Unusual phosphate minerals and diatom-bearing stalactites from the Farallon Islands. Calif. Geol. 47, 78-83.

Vernet, J.P., 1962. L'halloysite bleue du mount Vuache (Savoie). Comptes Rendus Hebdom. Seances Acad. Sci. 254, 2377-2379.

Wilmot, R.D., Young, B., 1985. Aluminite and other aluminium minerals from Newhaven, Sussex: the first occurrence of nordstrandite in Great Britain. Proc. Geol. Assoc. 96, 47-52. 